\begin{tabular}{l|c|c}
\hline ISSN: 0001-5113 & ACTA ADRIAT., & REVIEW PAPER \\
AADRAY & 58(1): 165 - 186, 2017 & RET \\
\hline
\end{tabular}

\title{
The abundance, distribution and speciation of mercury in waters and sediments of the Adriatic Sea - a review
}

\author{
Igor ŽIVKOVIĆ ${ }^{1,2}$, Jože KOTNIK ${ }^{1}$, Mladen ŠOLIĆ ${ }^{3}$ and Milena HORVAT H,2,* $^{1,2}$ \\ ${ }^{1}$ Jožef Stefan Institute, Jamova cesta 39, SI-1000 Ljubljana, Slovenia \\ ${ }^{2}$ Jožef Stefan International Postgraduate School, Jamova cesta 39, SI-1000 Ljubljana, Slovenia \\ ${ }^{3}$ Institute of Oceanography and Fisheries, Šetalište I. Meštrovića 63, HR-21000 Split, Croatia \\ *Corresponding author, e-mail: milena.horvat@ijs.si
}

This review focuses on mercury speciation in the Adriatic Sea, a marginal sea of the Mediterranean, which represents its distinct biogeochemical subunit due to anthropogenic mercury loadings. The current knowledge about mercury cycling in the Adriatic is presented through an overview of the state of the art of research in this area: temporal and spatial distributions and occurrence of mercury species in seawater and sediment, and chemical transformations. We summarised research results of mercury speciation in order to describe its presence and fate in the Adriatic Sea. The Adriatic Sea represents a net source of mercury to the Mediterranean Sea due to the highest total mercury concentrations observed in the North Adriatic Sea and the highest methylmercury concentrations in the South Adriatic Pit. However, the biogeochemical cycle of mercury is not completely known and our understanding of mercury transport between compartments and its (bio)transformations is limited. Future research needs to focus on microbial and chemical processes of mercury transformations to improve our understanding of the impacts of mercury contamination on the environment and human health in the Adriatic Sea.

Key words: mercury, chemical speciation, methylmercury, Adriatic, Mediterranean

\section{INTRODUCTION}

Among trace metals, mercury $(\mathrm{Hg})$ is one of the contaminants of most concern because of its high toxicity, persistence and accumulative behaviour in the environment and biota (UNEP, 2013). The atmosphere is the most important medium that transports $\mathrm{Hg}$ around the globe (SPROVIERI et al., 2010). Gaseous mercury can reside in the atmosphere and be transported over large geographical distances and exchanged with land or surface waters. Hence, mercury contamination is a global environmental prob- lem (AMAP/UNEP, 2013; UNEP, 2013). Due to transformation and transport processes, mercury can travel between environmental compartments: from atmosphere to water, soil and biota. The pathways and fate of mercury in the aquatic environment are important due to chemical and biological processes affecting speciation, partitioning and bioavailability of mercury (UNEP, 2013).

The chemical form of $\mathrm{Hg}$ in aquatic systems strongly depends on environmental conditions that determine its mobility and reactivity (AMAP/ UNEP, 2013), and the concentration of inorganic 
and organic complexing agents (FITZGERALD et al., 2007). In seawater, mercury has a very reactive chemistry. It can be present in different forms, whether dissolved or bound to particulates. The main dissolved $\mathrm{Hg}$ fractions are dissolved elemental mercury (DEM), $\mathrm{Hg}$ (II) complexes with organic and/or inorganic ligands, reactive mercury ( $\mathrm{RHg}$ ), and organomercury compounds (methylmercury $(\mathrm{MeHg})$ and dimethylmercury (DMHg)) (HORVAT et al., 2003; O'DRISCOLL et al., 2005). Binding of mercury species onto particulate matter in water causes their settling and burying in sediments, which is a major pathway for removal of mercury from the biologically active environment (UNEP, 2013). Remobilisation from sediments is an important source of $\mathrm{Hg}$ to coastal and open marine systems and potentially to biota (ŽAGAR et al., 2013). Most mercury enters the marine environment by wet or dry deposition, with a significant fraction in oxidised form (SOERENSEN et al., 2010; ZHANG et al., 2009). Exceptions are small, semi-enclosed basins where river discharges, coastal erosion and ocean currents account for half of mercury input (UNEP, 2013). Rivers are the most important sources of mercury contamination from land. While riverine $\mathrm{Hg}$ inputs dominate in coastal watershed systems, combined atmospheric and riverine inputs are observed in "multiple-input" waters (CHEN et al., 2016). Major part of deposited mercury into the ocean is re-emitted to the atmosphere. Due to supersaturation, mercury emitted from open ocean to the atmosphere is mostly $\mathrm{Hg}^{0}$, whereas the majority of deposited $\mathrm{Hg}$ is oxidised mercury (SPROVIERI et al., 2010). It is easily deposited to surface waters by wet deposition because of high solubility (HEDGECOCK et al., 2003; HOLMES et al., 2009; SPROVIERI et al., 2003).

Surface seawater, especially its euphotic zone, is an important compartment for the global $\mathrm{Hg}$ biogeochemical cycle (UNEP, 2013). Volatile $\mathrm{Hg}$ species (DGM; sum of DEM and DMHg) diffuse from deep ocean waters to the surface and evaporate into the atmosphere. The major sources of DGM are biological processes in deep and surface waters (DRISCOLL et al., 2013; LANZILLOTTA et al., 2002), as well as geothermal/ hydrothermal fields at the sea bottom (FANTOZZI et al., 2009; FERRARA et al., 2000; HORVAT et al., 2003; PIRRONE et al., 2010). In surface waters, photoreduction and photooxidation are two important driving forces for the DEM cycle (COSTA \& LISS, 1999; LANZILLOTTA et al., 2002; QURESHI et al., 2010). DMHg can be the dominant $\mathrm{Hg}$ specie in the deeper waters (MASON et al., 2012) but it readily evades from surface waters and is photochemically degraded (FITZGERALD et al., 2007; FITZGERALD \& LAMBORG, 2003). Mercury chemistry in the open Mediterranean waters is very reactive, which results in elevated $\mathrm{MeHg}$ and DGM concentrations (MONPERRUS et al., 2007a). MeHg produced in the sediments by sulphate reducing bacteria can be released to the overlying water (EMILI et al., 2011, 2014; KORON \& FAGANELI, 2012; MONPERRUS et al., 2007b) and could constitute an important source of the $\mathrm{MeHg}$ content in marine biota. However, the estimated methylated mercury fluxes in the ocean suggest that riverine input, coastal sources and atmospheric deposition are insufficient to explain observed methylated $\mathrm{Hg}$ sinks in the ocean (bioaccumulation, removal by fisheries, photochemical and biological degradation, and direct removal to the deep ocean and sediments) (MASON et al., 2012). Findings based on detailed $\mathrm{MeHg}$ profiles support the hypothesis that in situ sources of $\mathrm{MeHg}$ are dominant over advection (COSSA et al., 2009). There are two zones of $\mathrm{MeHg}$ productivity connected to the re-mineralisation of organic carbon in the water column: first in the bottom of the euphotic layer (COSSA et al., 2009, 2011; HEIMBÜRGER et al., 2010) and the other at the oxygen minimum in the sub-thermocline (BOWMAN et al., 2015; HAMMERSCHMIDT \& BOWMAN, 2012; HEIMBÜRGER et al., 2010). Conversely, photochemical and microbial demethylations of $\mathrm{MeHg}$ are the major removal processes of $\mathrm{MeHg}$ in the ocean (FITZGERALD et al., 2007; LEHNHERR et al., 2011).

Microbial activity can convert inorganic mercury into $\mathrm{MeHg}$, which is rapidly incorporated into the food web and biomagnifies throughout trophic levels. $\mathrm{MeHg}$ is a powerful neurotoxin affecting fish and wildlife (UNEP, 2013). Due to its toxicological properties, pos- 
sible presence in food, and transfer to humans, $\mathrm{MeHg}$ is the most important form of mercury; fish and aquatic biota are the predominant food sources involved in human exposure (AMAP/ UNEP, 2013).

Sea represents a significant part of the mercury cycle in the environment. The Mediterranean and Adriatic Sea are especially important due to the presence of natural and anthropogenic sources of mercury contamination. Research results in the Mediterranean and Adriatic Sea have demonstrated that mercury is present in elevated concentrations in biota (BERTO et al., 2006; CULLAJ et al., 2004; GIANI et al., 2012; HORVAT et al., 2014; KLJAKOVIĆ-GAŠPIĆ et al., 2006; MIKAC et al., 1989; STORELLI et al., 1998; TROMBINI et al., 2003) compared to the Atlantic Ocean. The objective of this paper is to describe mercury contamination and emphasise the importance of its speciation in the Adriatic Sea as a biogeochemical subunit of the Mediterranean Sea. We evaluate the current state in the Adriatic Sea by presenting relevant spatial and temporal changes in mercury concentration in different compartments.

\section{STUDY AREA}

The Mediterranean Sea is an enclosed basin that includes large but diverse coastal and marine ecosystems. Strait of Sicily separates Western and Eastern basins, each comprised of four seas (Fig. 1). The Mediterranean Sea connects to the Atlantic Ocean through the Strait of Gibraltar and to the Black Sea through the BosporusMarmara-Dardanelles system. The Adriatic Sea is an elongated basin and the northernmost part of the Mediterranean Sea with which water is exchanged through the Strait of Otranto (Fig. 1). The Adriatic Sea is $783 \mathrm{~km}$ long and about $200 \mathrm{~km}$ wide (UNEP, 2012). It is divided into three regional basins (north, central and south)

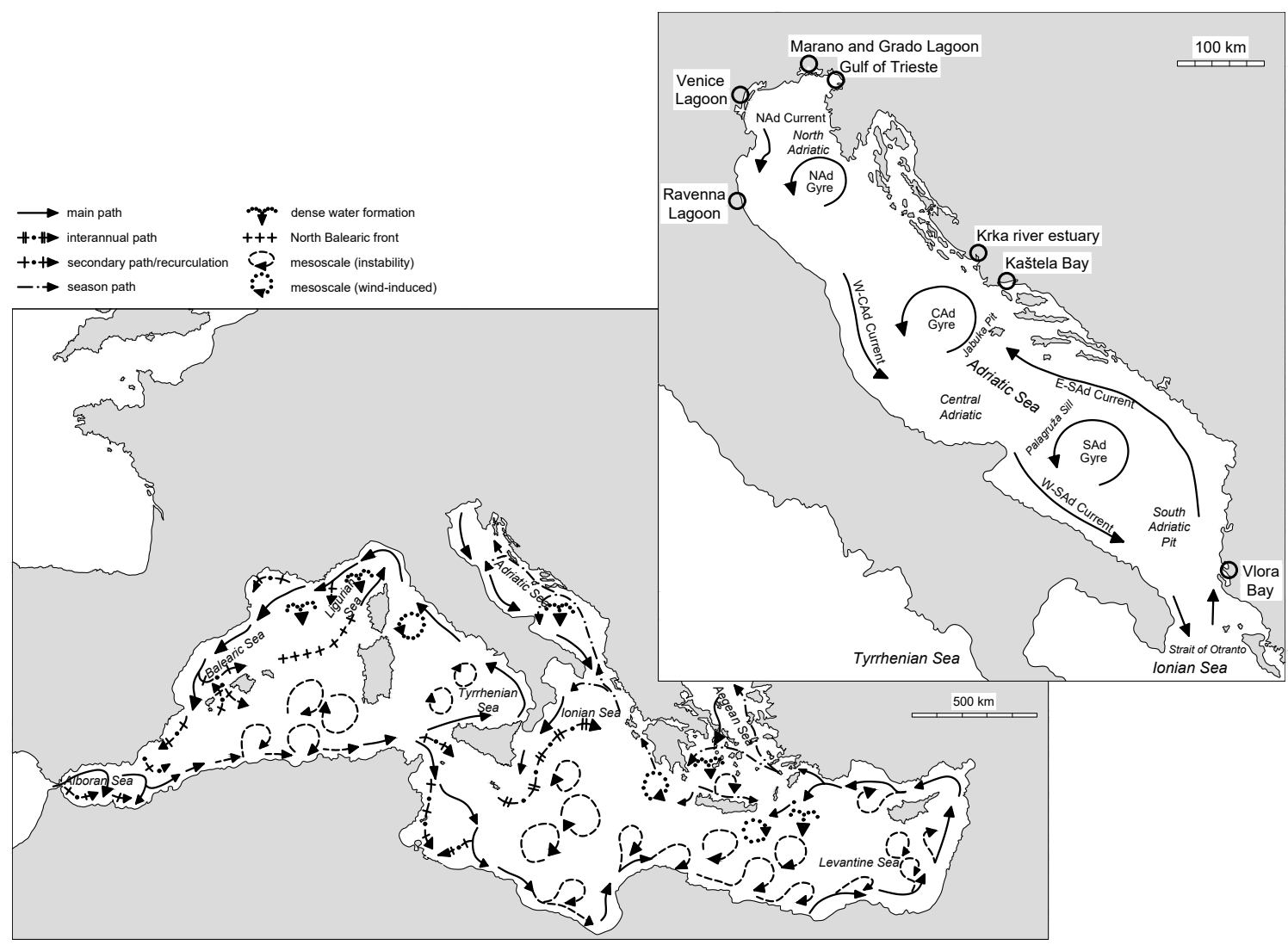

Fig. 1. Surface water circulation flows and geographical divisions of the Mediterranean and the Adriatic Sea. Redrawn from KOTNIK et al. (2015) and MILLOT \& TAUPIER-LETAGE (2005) 
which differ in latitude, bathymetry, physiography and biogeochemical characteristics (UNEP, 2012). Northern Adriatic is very shallow with an average bottom depth of $35 \mathrm{~m}$. The central part is on average $140 \mathrm{~m}$ deep while the southern end is characterised by a wide depression $(\sim 1250 \mathrm{~m})$ (BENSI et al., 2014). The Adriatic water circulation (Fig. 1) is dominated by North Adriatic current (N-Ad current), cyclonic Central and Southern Adriatic gyres (CAd and SAd), eastern South Adriatic current (E-SAd current) and western South Adriatic current (W-SAd current). Three water masses (surface water, Levantine intermediate water and deep water) were identified in three sub-basins of the Adriatic Sea by their physical properties (ARTEGIANI et al., 1997). Thermocline is present in spring and summer down to $30 \mathrm{~m}, 50 \mathrm{~m}$ and $75 \mathrm{~m}$ in the North, Central and South Adriatic Sea, respectively (ARTEGIANI et al., 1997). The Po River is the most important river regarding freshwater discharge $\left(1550 \mathrm{~m}^{3}\right.$ $\mathrm{s}^{-1}$ ) (ŽAGAR et al., 2013) and contributes to $46.5 \%$ of the overall freshwater input (UNEP, 2012). Most of the freshwater input is in the north-western Adriatic, while only $27 \%$ is discharged in the eastern side (UNEP, 2012). Sediments input from the Po River is $\sim 15 \times 10^{6} \mathrm{t} \mathrm{a}^{-1}$ (NITTROUER et al., 2004) while the overall input to the northern and central Adriatic is $46.6 \times 10^{6} \mathrm{t} \mathrm{a}^{-1}$ (FRIGNANI et al., 2005). Sediments originating from the Po River consist mainly of silt and clay (COMBI et al., 2016; NITTROUER et al., 2004). The sea bottom in the eastern Adriatic is rocky with corallogenic concretions along the islands (UNEP, 2012).

\section{MERCURY IN THE MEDITERRANEAN SEA}

The Mediterranean Sea is subject to mercury contamination from natural and anthropogenic sources. Although it covers only about $1 \%$ of the world oceans, almost $65 \%$ of the world mercury reserves are situated in the cinnabar belt under the Mediterranean area (ŽAGAR et al., 2013). The most important Hg sources in the Mediterranean (in $\mathrm{t}^{-1}$ ) are atmospheric deposition (38), river inflow (13) and sediments (19), while the main outputs are evasion to atmosphere (68)

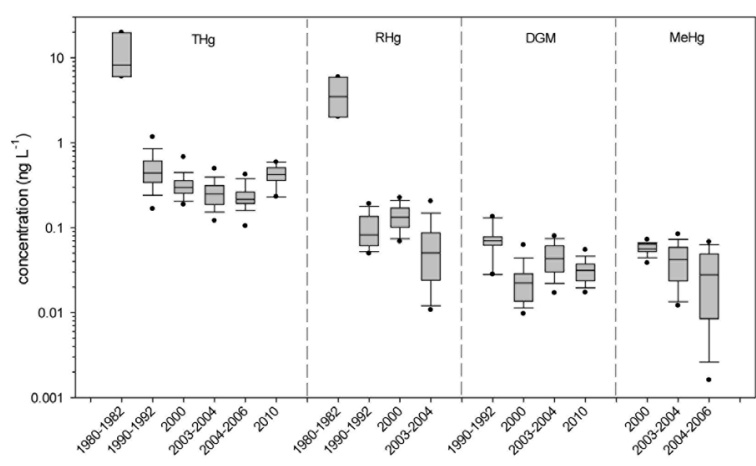

Fig. 2. Box-and-whisker plots of THg, RHg, DGM and $\mathrm{MeHg}$ concentrations in the Mediterranean Sea from 1980-2010 (median with 5, 10, 25, 75, 90 and 95th percentiles). Data from COSSA et al., 1997, 2009; FANTOZZI et al., 2013; FERRARA et al., 1986, 2003; HORVAT et al., 2003; KOTNIK et al., 2007

and burial in the sediments (25) (ŽAGAR et al., 2013). The Mediterranean Sea is slowly coping with mercury contamination because $\mathrm{Hg}$ output exceeds the input by about $5 \mathrm{t} \mathrm{a}^{-1}$.

In the 1970s, THg values in some Mediterranean pelagic fish were two fold higher than those in the same species living in the Atlantic Ocean (COSSA \& COQUERY, 2005), which raised questions about $\mathrm{Hg}$ contamination in the Mediterranean. High THg concentrations were also observed in water. Even though BERNHARD (1988) reported THg concentrations higher than $10 \mathrm{ng} \mathrm{L}^{-1}$, it was stated that the validity of this data is doubtful. Since then, measured concentrations have been decreasing in the last decades (Fig. 2), mainly because more attention has been given to sample contamination during sampling, storage and analysis (BERNHARD, 1988; HORVAT, 2005), and because of using more sensitive instrumentation, mainly atomic fluorescence spectrometry (HORVAT, 2005).

Average $\mathrm{THg}$ concentration in the entire open Mediterranean Sea is $0.29 \pm 0.12 \mathrm{ng} \mathrm{L}^{-1}$ and is comparable in all measured water masses in the basin (KOTNIK et al., 2013). The highest concentrations are always found in coastal areas (FANTOZZI et al., 2013; KOTNIK et al., 2015). The highest open sea $\mathrm{THg}\left(0.71 \mathrm{ng} \mathrm{L}^{-1}\right)$ is found in the surface water in the Strait of Sicily, probably due to elevated geotectonic activity in this area (KOTNIK et al., 2007). Most of mercury in the open waters is present in dissolved form (avg. 

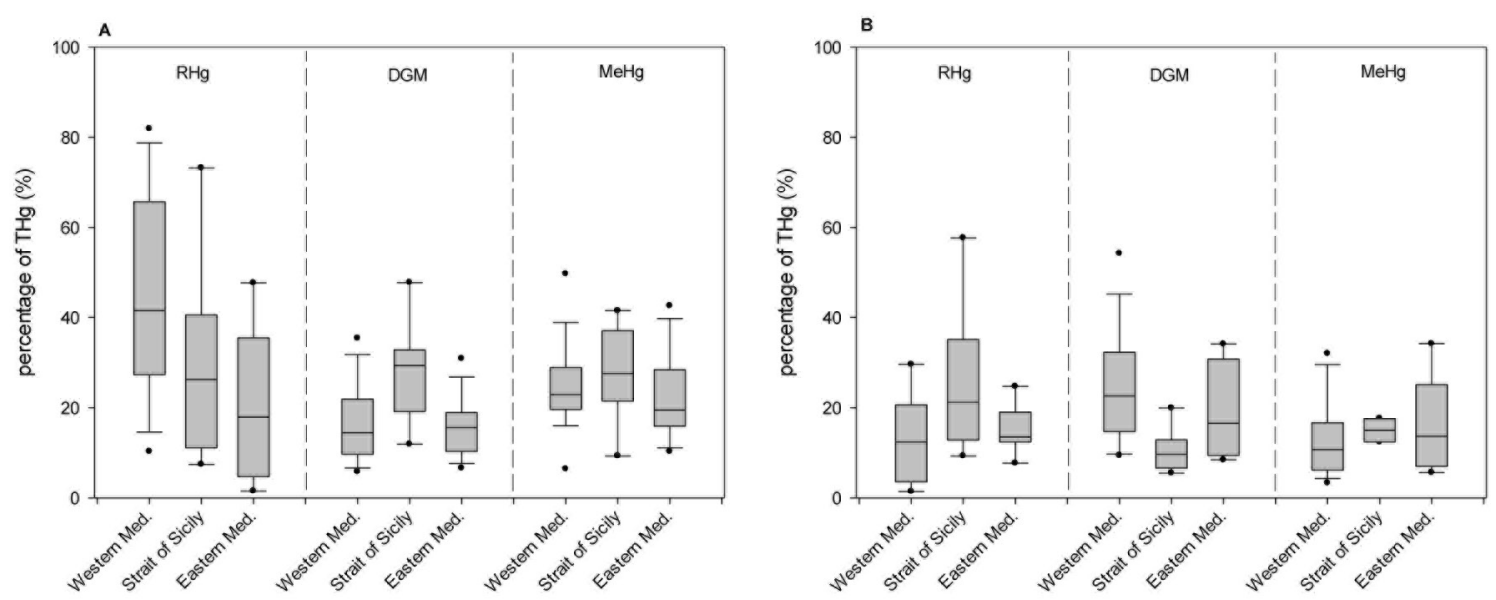

Fig. 3. Box-and-whisker plots of the geographical distribution of RHg, DGM and MeHg percentage of THg during spring (A) and summer (B) in the Mediterranean Sea. Data from KOTNIK et al., 2007

$70 \%$, due to the low abundance of particulate matter (HORVAT et al., 2003). The concentrations of various $\mathrm{Hg}$ compounds are lower than those in world oceans, despite the geological mercury anomaly (KOTNIK et al., 2013). Major factors influencing the distribution of $\mathrm{RHg}$ in the Mediterranean Sea are the presence of volcanic, geotectonic and biological activity, and photochemical reactions (KOTNIK et al., 2007). RHg is lower in the summer than in the spring (KOTNIK et al., 2007), as is its percentage of THg (Fig. 3). $\mathrm{RHg}$ vertical profiles are mostly the opposite of DGM, as inorganic $\mathrm{Hg}$ is a substrate for DGM production (KOTNIK et al., 2013). Most of DGM is DEM, indicating its geotectonic origin. DGM generally increases with depth; this suggests the existence of volatile $\mathrm{Hg}$ sources in deeper waters (KOTNIK et al., 2013), bacterial activity in the oxygen-depleted waters (KOTNIK et al., 2007), or the oxidation of $\mathrm{Hg}^{0}$ in the presence of UV light and chlorine/bromine (HORVAT et al., 2003) or hydroxyl radical (GÅRDFELDT et al., 2001) in the surface waters. The average $\mathrm{MeHg}$ concentration is higher during the spring $(56.2 \pm 24.1$ pg $\left.\mathrm{L}^{-1}\right)$ than during the summer $(32.1 \pm 20.1 \mathrm{pg}$ $\mathrm{L}^{-1}$ ) (KOTNIK et al., 2007). The highest concentrations are usually found in the bottom water layer, indicating input from sediment (OGRINC et al., 2007), microbially mediated methylation in deeper waters, or photochemical/microbial remineralisation of sinking organic matter from the surface waters (KOTNIK et al., 2007). In addi- tion, particulate scavenging can remove $\mathrm{MeHg}$ from surface waters and release it into deeper waters through particulate dissolution (COSSA et al., 2009). $\mathrm{MeHg} / \mathrm{THg}$ ratio (Fig. 3) follows the variability of $\mathrm{MeHg}$ concentration; it is higher in spring than in summer. This could be due to the higher biological activity (significantly higher chlorophyll levels) occurring in spring; however, $\mathrm{MeHg}$ concentrations are only slightly elevated, not statistically significant (KOTNIK et al., 2007). The vertical distribution of $\mathrm{DMHg}$ depends on the presence of the thermocline. Levels below limit of detection are found in the surface layer, while the highest concentrations ( $2.43 \mathrm{pg} \mathrm{L}^{-1}$ ) are measured in the deep waters (COSSA et al., 1997; HORVAT et al., 2003; KOTNIK et al., 2007). Similar to $\mathrm{MeHg}, \mathrm{DMHg} / \mathrm{THg}$ ratio is higher during spring than summer. Since the Mediterranean deep waters are $\sim 10^{\circ} \mathrm{C}$ warmer than the Atlantic waters of the same depth, more microbially mediated methylation could occur due to its temperature dependence (COSSA et al., 1997; COSSA \& COQUERY, 2005).

Mercury accumulation rates in the Mediterranean sediments range from 10.3-30.9 ng $\mathrm{m}^{-2} \mathrm{~d}^{-1}$ and 2.59-4.93 $\mathrm{ng} \mathrm{m}^{-2} \mathrm{~d}^{-1}$ in the Western and Eastern basins, respectively (OGRINC et al., 2007). THg concentrations in the sediments of the western basin decrease from the surface (78.2-90.3 $\mathrm{ng} \mathrm{g}^{-1}$ ) and at a depth of $10 \mathrm{~cm}$ the concentrations are within the range of the earth crust values (OGRINC et al., 2007; COSSA \& 
COQUERY, 2005). THg concentrations in the Eastern Mediterranean sediment are lower (COSSA \& COQUERY, 2005). THg distribution in deeper layers may reflect redistribution during diagenetic processes or changes in the sedimentation conditions (OGRINC et al., 2007). The highest $\mathrm{MeHg}$ concentrations (up to $2.97 \mathrm{ng} \mathrm{g}^{-1}$ ) are generally found in the uppermost sediment layer and decrease with sediment depth. Methylation potentials for surface sediments are in the range $0.16-0.71 \% \mathrm{~d}^{-1}$ and generally follow the $\mathrm{MeHg}$ depth profile (OGRINC et al., 2007).

\section{MERCURY IN THE ADRIATIC SEA}

\section{Distribution of mercury species in seawaters}

Total mercury in the seawater exhibits a concentration gradient: the lowest values are found in the southern area and increase in the central part, while the highest values are found in the Northern Adriatic (Fig. 4A) (FERRARA \& MASERTI, 1992; KOTNIK et al., 2015). As in the Mediterranean Sea, there is a decrease in measured $\mathrm{THg}$ concentrations with time in the Adriatic Sea (Fig. 5), probably due to questionable validity of older data and possible sample contamination. Another possibility is a real decrease of $\mathrm{Hg}$ concentrations due to the closure of the Idrija mine in 1994 (FAGANELI et al., 2003).

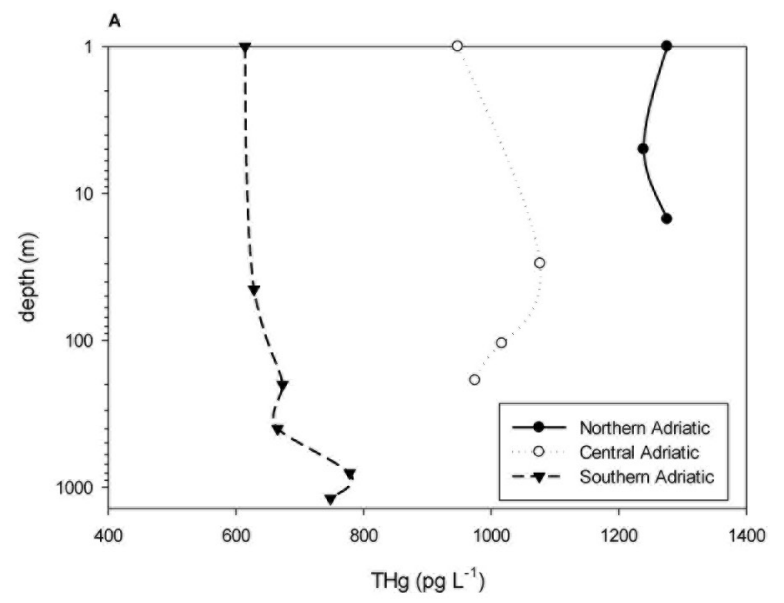

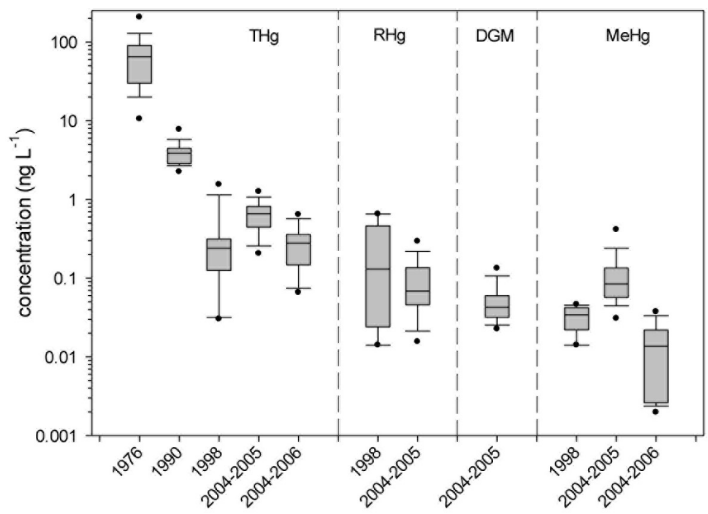

Fig. 5. Box-and-whisker plots of THg, RHg, DGM and $\mathrm{MeHg}$ concentrations in the Adriatic Sea from 19762005 (median with 5, 10, 25, 75, 90 and 95th percentiles). Data from COSSA et al., 2009; FERRARA \& MASERTI, 1992; HORVAT et al., 2003; KOSTA et al., 1978; KOTNIK et al., 2015

Generally, average $\mathrm{THg}$ concentrations in the open Adriatic Sea are low (up to $0.32 \mathrm{ng}$ $\mathrm{L}^{-1}$ in uncontaminated sites), which is similar to the values found in the open Mediterranean Sea (HORVAT et al., 2003). The highest THg values are observed at the Otranto Strait at a depth of $40 \mathrm{~m}$ in summer $\left(0.381 \mathrm{ng} \mathrm{L}^{-1}\right)$ and at $600 \mathrm{~m}$ in spring (0.379 $\left.\mathrm{ng} \mathrm{L}^{-1}\right)$ (KOTNIK et al., 2007). Vertical salinity gradient indicates downwelling of surface Adriatic seawater; anthropogenic mercury pollution could be the reason for observed $\mathrm{Hg}$ peaks within this gradient (KOTNIK et al., 2007). Elevat-

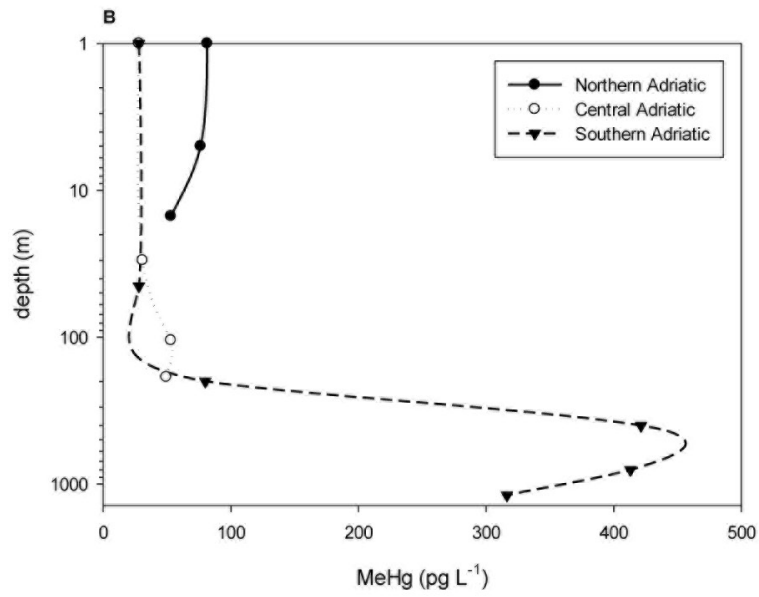

Fig. 4. Vertical seawater profiles of $\mathrm{THg}(A)$ and $\mathrm{MeHg}(B)$ in the Northern, Central and Southern Adriatic Sea. Data from KOTNIK et al., 2015 
ed $\mathrm{THg}$ concentrations in the bottom water layer of the southern Adriatic Sea (Fig. 4A) could be due to southward transfer of the downwelling surface waters from the contaminated northern Adriatic Sea. Wide range in the THg associated with suspended particulate matter (SPM) can be observed in the three parts of the Adriatic Sea, with the highest values found in the northern Adriatic. The major sources of mercury bound to SPM are the Isonzo River (microcrystalline cinnabar), the Marano and Grado lagoon and the Po river delta. Generally, the amount of $\mathrm{Hg}$ associated with the SPM is often comparable or higher than that of the dissolved fraction (COVELLI et al., 2006b, 2007; FERRARA \& MASERTI, 1992).

COSSA et al. (2009) made vertical profiles of methylated mercury species (MeHg+DMHg) in the Mediterranean Sea, which were the first high-resolution profiles showing consistent features. All the vertical profiles, including Adriatic, exhibit similar patterns: very low concentrations of methylated mercury species in the surface waters, a sharp gradient within the biologically most active zone $(0-600 \mathrm{~m})$, an intermediate maximum (200-1000 m) and lower concentrations in the deep waters (COSSA et al. 2009; HEIMBÜRGER et al. 2010). KOTNIK et al. (2015) obtained a similar vertical profile in the southern Adriatic (Fig. 4B). The highest $\mathrm{MeHg}$ concentrations $\left(0.50 \mathrm{ng} \mathrm{L}^{-1}\right)$ and the highest percentage of THg as MeHg (Fig. 6) were measured in the bottom water of the eastern South Adriatic shore. These concentrations were considerably higher than values reported in the Mediterranean Sea (COSSA et al., 2009; HORVAT et al., 2003; KOTNIK et al., 2007). Even in the most contaminated northern Adriatic, no significant increase in $\mathrm{MeHg}$ concentration along the water column is observed. The highest concentrations of methylated mercury species are not found near the shelf edge, suggesting that the sediments of the continental shelf are not the main $\mathrm{MeHg}$ source for the water column in the open sea (COSSA et al., 2009). MeHg production is the greatest in the deeper central and southern Adriatic waters (southern Adriatic Pit), probably due to biological or chemical processes, an unknown benthic source or slower removal of $\mathrm{MeHg}$ from the

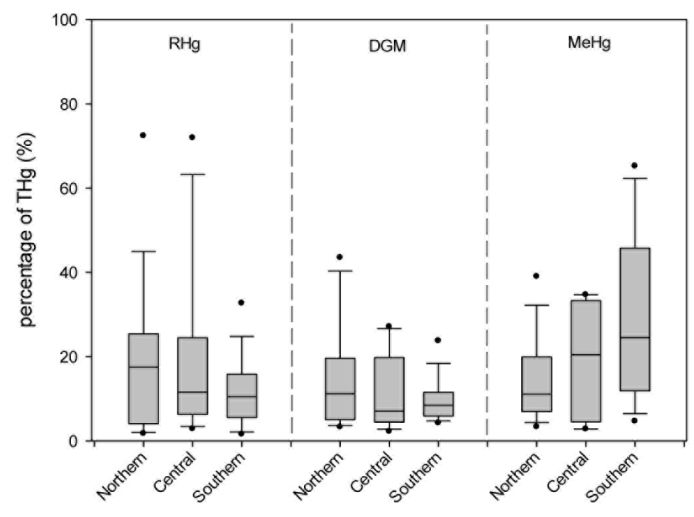

Fig. 6. Box-and-whisker plots of the geographical distribution of $\mathrm{RHg}, \mathrm{DGM}$ and $\mathrm{MeHg}$ percentage of $\mathrm{THg}$ in the Adriatic Sea. Data from KOTNIK et al., 2015

water column (KOTNIK et al., 2015). KOTNIK et al. (2007) measured DMHg below the detection limit $\left(80 \mathrm{fg} \mathrm{L}^{-1}\right)$ at the Strait of Otranto. The average concentration of $\mathrm{DMHg}$ in Adriatic waters is $1.1 \mathrm{pg} \mathrm{L}^{-1}$, while significantly lower values are found in the northern Adriatic (KOTNIK et al., 2015). However, elevated concentrations of DMHg (up to $4.7 \mathrm{pg} \mathrm{L}^{-1}$ ) are found near the island of Vis above the sea bottom, and in deep waters of the Southern Adriatic Sea. On average, DMHg represents $1.7 \%$ of THg. Differences between concentrations in the Adriatic and Mediterranean Sea are probably due to various anthropogenic sources (e.g. chlor-alkali plants, the Idrija mercury mine) (KOTNIK et al., 2015) which provide sufficient substrate for methylation in this semi-enclosed sub-basin.

DGM is relatively low in surface waters and usually shows a steady increase towards the bottom during summer and spring (KOTNIK et al., 2007), which reflects the importance of evasion and photochemical reactions at the surface (HORVAT et al., 2003). In deeper waters, DGM distribution indicates the importance of redox processes, microbial production, diffusion from sediment and/or geothermal/hydrothermal fields, especially at locations in the southern Adriatic Pit, which is tectonically very active (KOTNIK et al., 2013). DGM spatial distribution mostly follows THg distribution; the highest concentrations and percentages are found in the northern Adriatic (Fig. 6), reflecting anthropogenic sources (KOTNIK et al., 2015). Correlations between maximum 
DGM and RHg, and the oxygen-depleted zone are usually observed (KOTNIK et al., 2013). Spatial distribution of RHg usually follows that of $\mathrm{THg}$; the highest concentrations are found in the most contaminated parts of the northern Adriatic (up to $0.37 \mathrm{ng} \mathrm{L}^{-1}$ ) (KOTNIK et al., 2015).

\section{Mercury in the Adriatic sediment}

Mercury distribution in the open Adriatic sediments was investigated in the 1970s and 1980 s, but these research mostly covered the open northern Adriatic. We will present results from these studies, and although some values can be compared with recent results, it cannot be systematically performed due to lack of data, mainly $\mathrm{MeHg}$ concentrations. Mercury in the sediment of the Gulf of Trieste mainly originates from the discharge of the Soča/Isonzo River, which has been draining cinnabar-rich deposits of the Idrija mine for centuries (COVELLI et al., 2001, 2007; FAGANELI et al., 2003). The effect of fluvial contribution, sediment re-suspension and the presence of localized natural and anthropogenic mercury sources can explain the observed highest THg levels in the northern Adriatic Sea

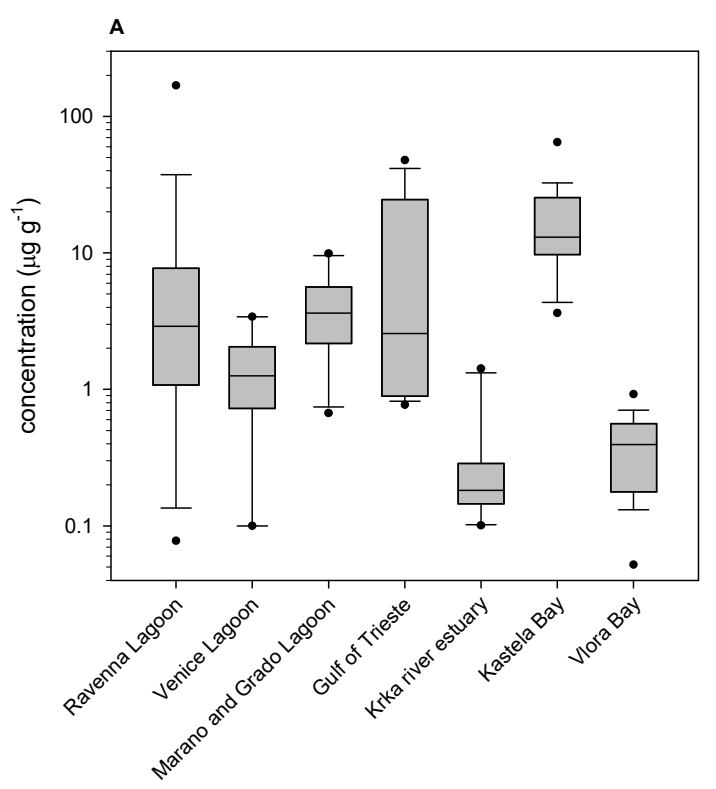

(Fig. 7). The largest anthropogenic $\mathrm{Hg}$ sources are chlor-alkali/PVC factories that had used mercury in their technological processes (ACQUAVITA et al., 2012; CULLAJ et al., 2004; GUÉDRON et al., 2012; KWOKAL et al., 2002).

Previous studies found that $\mathrm{THg}$ in the sediments of the open northern Adriatic range from $<0.1-16.9 \mu \mathrm{g} \mathrm{g}^{-1}$ (DONAZZOLO et al., 1984) with an average of $0.78 \mu \mathrm{g} \mathrm{g}^{-1}$ (MANTOVAN et al., 1985). Frequency histogram shows that $64 \%$ of samples have $<0.4 \mu \mathrm{g} \mathrm{g}^{-1}$ (DONAZZOLO et al., 1984). The same percentage was reported by GUERZONI et al. (1984) for the open Adriatic sediments between Ancona and the Po River mouth. Decreasing THg gradient from the Po River mouth $\left(0.97 \mu \mathrm{g} \mathrm{g}^{-1}\right)$ to Pesaro $\left(0.06 \mu \mathrm{g} \mathrm{g}^{-1}\right)$ indicates that the Po River has an outstanding role in the trace metal pollution of this area (FRIGNANI et al., 1976, 1978). The average THg concentrations in the Gulf of Venice $\left(0.56 \mu \mathrm{g} \mathrm{g}^{-1}\right)$ (DONAZZOLO et al., 1981), in surface sediments offshore the Po River mouth $\left(0.4 \mu \mathrm{g} \mathrm{g}^{-1}\right)$ (FRASCARI et al., 1988; GUERZONI et al., 1985), and at the dredge disposal site outside the Ravenna harbour $\left(0.28 \mu \mathrm{g} \mathrm{g}^{-1}\right)$ (GIANI et al., 1994; PELLEGRINI et al., 1992) are in the range observed for the open northern Adri-

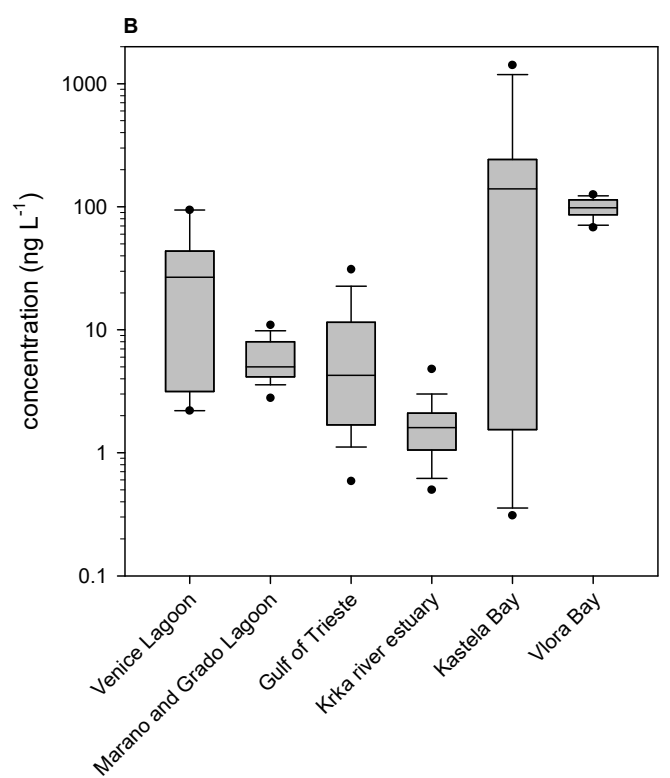

Fig. 7. Box-and-whisker plots of THg in sediments (A) and water (B) of the case studies. Data obtained from: ACQUAVITA et al., 2012; ANCONELLI et al., 1980; BERTO et al., 2006; BILINSKI et al., 2000; BLOOM et al., 2004; CULLAJ et al., 2004; FAGANELI et al., 2003; HINES et al., 2000; HORVAT et al., 1999, 2003; KOTNIK et al., 2015; KWOKAL et al., 2002; KWOKAL \& LOVRIĆ, 2006; LAZO \& CULLAJ, 2002; MELAKU CANU et al., 2015; MIKAC et al., 2006; QARRI et al., 2014; TROMBINI et al., 2003 
atic sediments. In the southern Adriatic, $\mathrm{THg}$ in sediments range from $0.07-0.97 \mu \mathrm{g} \mathrm{g}^{-1}$, with a median of $0.1 \mu \mathrm{g} \mathrm{g}^{-1}$ (SELLI et al., 1973). FERRARA \& MASERTI (1992) measured THg concentrations in the sediments of all three sub-basin of the Adriatic Sea. The concentration ranges are 0.05-8.63, 0.02-0.13 and 0.03-0.07 $\mu \mathrm{g} \mathrm{g}^{-1}$ in the northern, central and southern Adriatic sediments, respectively. This is in a good agreement with the results from KOSTA et al. (1978) (0.01-15.1, 0.02-0.07, and 0.01-0.11 $\mu \mathrm{g} \mathrm{g}^{-1}$ in the northern, central and southern Adriatic sediments, respectively). These concentrations exhibit the north-south gradient and emphasize the influence of localised natural and anthropogenic sources on $\mathrm{Hg}$ distribution. Mercury is mostly (95\%) accumulated in the fine fraction of the sediment (DONAZZOLO et al., 1984). The average $\mathrm{THg}$ concentration in offshore surface muds $\left(0.34 \mu \mathrm{g} \mathrm{g}^{-1}\right)$ is higher than in offshore relict of the northern Adriatic (mostly sand; $0.10 \mu \mathrm{g} \mathrm{g}^{-1}$ ) which reflects the observed positive correlation between THg and clay/mud (DONAZZOLO et al., 1981; GUERZONI et al., 1984).

Recent research shows that $\mathrm{THg}$ concentrations in the Adriatic sediments can vary more than 150-fold among locations, depending on the loading sources (KOTNIK et al., 2015). In the offshore sediments, $\mathrm{THg}$ concentrations $\left(0.02-0.26 \mu \mathrm{g} \mathrm{g}^{-1}\right)$ are in range with the values observed in the Mediterranean. The average concentration in unpolluted areas of the Central and South Adriatic is $0.12 \mu \mathrm{g} \mathrm{g}^{-1}$ (KOTNIK et al., 2015) and is comparable with the previous measurements. In the coastal sediments (not including industrial hot-spots), $\mathrm{THg}$ values range from $0.10 \mu \mathrm{g} \mathrm{g}^{-1}$ in the Krka river estuary (KWOKAL et al., 2002) to $47.8 \mu \mathrm{g} \mathrm{g}^{-1}$ in the Gulf of Trieste (HINES et al., 2000). In the sediments contaminated by industrial activity, $\mathrm{THg}$ range from $0.05-250$ $\mu \mathrm{g} \mathrm{g}^{-1}$ (Fig. 7A). Based on the sedimentation rates, sediment porosity and density, calculated mercury accumulation rates in the Adriatic sediments range from $12.0-148 \mathrm{ng} \mathrm{m}^{-2} \mathrm{~d}^{-1}$ (KOTNIK et al., 2015). These values are up to 14 and 57 times higher than in the Western and Eastern Mediterranean, respectively.

In front of the Po river plume, THg concentrations in sediment are characterised by a two-fold decrease from the top layer to the deep core (FOWLER et al., 1999; GUERZONI et al., 1985). Similarly, THg vertical profile is characterised by 2 to 6 -fold surface enrichment with respect to background levels outside the Ravenna harbour (GIANI et al., 1994), and 3 to 11-fold in the northern Adriatic sediment (FABBRI et al., 2001). The background THg levels in the northern Adriatic cores are estimated to $0.10-0.12 \mu \mathrm{g} \mathrm{g}^{-1}$ (DONAZZOLO et al., 1984; GUERZONI et al., 1984, 1985; FRASCARI et al., 1988). The maximum concentration of $\mathrm{THg}$ and $\mathrm{MeHg}$ at $22 \mathrm{~cm}$ depth is probably related to the year of maximum $\mathrm{Hg}$ production (i.e. 1913) when the Idrija mine produced double the annual $\mathrm{Hg}$ amount (FOWLER et al., 1999). $\mathrm{THg}$ concentrations in the southern Adriatic sediment decrease from the surface (12.2 $\left.\mathrm{ng} \mathrm{g}^{-1}\right)$ to the deeper levels. Similarly, vertical profile of $\mathrm{MeHg}$ concentrations at the Strait of Otranto shows maximum in the surface sediment $(2.94$ $\left.\mathrm{ng} \mathrm{g}^{-1}\right)$ and decreases with depth to the range of the crust values (OGRINC et al., 2007). Elevated $\mathrm{MeHg}$ concentrations at the Strait of Otranto are possibly a consequence of relatively high content of MeHg in the SPM, which is transported by water currents exiting the Adriatic Sea. During winter, sinking of surface water could cause the deposition of these particles onto the sediments (OGRINC et al., 2007).

In the uppermost two centimetres, $\mathrm{MeHg}$ in porewaters has the highest average value found for the whole Mediterranean (8.78 $\left.\mathrm{ng} \mathrm{L}^{-1}\right)$ (OGRINC et al., 2007). Vertical distribution of $\mathrm{RHg}$ and $\mathrm{MeHg}$ in porewaters are different; $\mathrm{RHg}$ is mostly constant while $\mathrm{MeHg}$ is constant in the uppermost four centimetres and then decreases with depth. Methylation potential for surface sediment is $0.14 \% \mathrm{~d}^{-1}$; this is one of the lowest values for the whole Mediterranean, which is unusual when taking into account high $\mathrm{MeHg}$ concentration in the sediment and porewaters. Sedimentation of SPM rich in $\mathrm{MeHg}$ at the Strait of Otranto could explain this observation (OGRINC et al., 2007). Estimated diffusive fluxes at the Strait of Otranto are $35.1 \mathrm{ng} \mathrm{m}^{-2} \mathrm{~d}^{-1}$ and $6.0 \mathrm{ng} \mathrm{m}^{-2} \mathrm{~d}^{-1}$ for $\mathrm{RHg}$ and $\mathrm{MeHg}$, respectively. These values are 3 to 5 -fold higher than corresponding fluxes in the western Mediterra- 
nean Sea (OGRINC et al., 2007). KOTNIK et al. (2015) calculated lower $\mathrm{MeHg}$ diffusive fluxes in the Adriatic (up to $3.35 \mathrm{ng} \mathrm{m}^{-2} \mathrm{~d}^{-1}$ ) indicating local restriction on input of $\mathrm{MeHg}$ from the sediment.

\section{Transport of mercury species in the Adriatic}

KOTNIK et al. (2015) estimated mercury transport and mass balance in the Adriatic Sea based on several contributions (Table 1). They calculated overall deficit of more than $5 \mathrm{t} \mathrm{a}^{-1}$ of $\mathrm{THg}$ and $2.3 \mathrm{t} \mathrm{a}^{-1}$ of $\mathrm{MeHg}$, and attributed it to additional $\mathrm{Hg}$ sources such as tectonic activity, dry deposition, and evasion overestimation. The greatest input fluxes are inflow from the Mediterranean Sea, terrestrial freshwater contributions (mainly Isonzo and Po rivers), and atmospheric deposition. Considering only seawater masses, the mass balance shows net import of inorganic $\mathrm{Hg}\left(0.6 \mathrm{t} \mathrm{a}^{-1}\right)$ and net export of $\mathrm{MeHg}$ $\left(2.4 \mathrm{t} \mathrm{a}^{-1}\right)$ to the Mediterranean Sea. As the South Adriatic Deep Water flows out to the Mediterranean Sea at $\sim 800 \mathrm{~m}$ depth (CIVITARESE \& GAČIĆ, 2001), it is carrying $\mathrm{Hg}$ to the Mediterranean deep waters. Considering that the highest $\mathrm{MeHg}$ concentrations are found in the South Adriatic Deep Water (KOTNIK et al., 2015), the Adriatic Sea exports methylated mercury into the Mediterranean Sea. The highest $\mathrm{THg}$ concentrations are usually found in the North Adriatic Surface Water. During cold and dry winters in the North Adriatic, this water mass cools, sinks and forms North Adriatic Deep Water (ARTEGIANI et al., 1997) resulting in southward transfer of mercury. Due to the marine current system in the Adriatic Sea (Fig. 1) that carries particulate matter from the river Po delta in anticlockwise direction, the western coast of the central Adriatic Sea exhibits elevated Hg concentrations in SPM (FERRARA \& MASERTI, 1992). Similarly, the greatest fraction of $\mathrm{THg}$ as RHg is found in the northern and central Adriatic (Fig. 6), but mostly along the western shore, indicating that inflowing water is not as reactive as outflowing water (KOTNIK et al., 2015). Alongside the outflow to the Mediterranean, evasion to the atmosphere is the most important route for $\mathrm{Hg}$ removal from the marine environment. Due to supersaturation of surface water with DEM, it easily escapes to the atmosphere (GÅRDFELDT et al., 2003), exceeding atmospheric deposition by a factor of 8. DGM in surface water shows higher values in the summer than in spring due to higher water temperatures and higher evaporation rates (KOTNIK et al., 2007). Based on the sedimentation rates, it appears that sediment is slowly removing both $\mathrm{THg}$ and $\mathrm{MeHg}$ from the water column.

\section{Case studies in the Adriatic Sea}

Coastal environments are areas of great ecological and economic importance, but also some of the most affected environments due to human activities. In the Adriatic Sea, coastal sites that bear the greatest $\mathrm{Hg}$ contamination are Ravenna Lagoon, Venice Lagoon, Marano and Grado Lagoon, the Gulf of Trieste, the Bay of Kaštela and the Bay of Vlora (Fig. 1). Pristine environment of the Krka river estuary is also a subject of mercury research. Different conditions in these coastal areas (redox potential, temperature, salinity, presence of methylating bacteria,

Table 1. Mercury mass balance in the Adriatic Sea. Data from KOTNIK et al., 2015. Negative values represent output fluxes from seawater

\begin{tabular}{ccc}
\hline Source & $\mathrm{THg}\left(\mathrm{t} \mathrm{a}^{-1}\right)$ & $\mathrm{MeHg}\left(\mathrm{t} \mathrm{a}^{-1}\right)$ \\
\hline Terrestrial freshwater contributions & 9.1 & 0.014 \\
"Hot spots" & 1.1 & 0.006 \\
Atmospheric deposition & 2.2 & \\
Evasion to atmosphere & $-16.2(\mathrm{as} \mathrm{DGM})$ & -0.62 \\
Sedimentation & -2.0 & 0.114 \\
Resuspension from sediment & 0.5 & 2.8 \\
Inflow from the Mediterranean & 11.2 & -5.2 \\
Outflow to the Mediterranean & -13.0 & $4.2 \mathrm{t}$ \\
\hline Present is seawater & $22.9 \mathrm{t}$ & \\
\hline
\end{tabular}


etc.) cause specific biogeochemical transformations of mercury.

\section{Ravenna Lagoon (Pialassa Baiona)}

Pialassa Baiona Lagoon mostly consists of shallow ponds. This lagoon received $\sim 38 \mathrm{t}$ of the estimated 100-200 $\mathrm{t}$ of $\mathrm{Hg}$ discharged by an acetaldehyde plant (1958-1978) (COVELLI et al., 2011). THg concentrations in sediments are variable and follow pollution gradient caused by northward water transport (TROMBINI et al., 2003). The highest $\mathrm{THg}$ concentrations $(250 \mu \mathrm{g}$ $\mathrm{g}^{-1}$ ) are found in the channel connected to the discharge of the plant, indicating the presence of dissolvable $\mathrm{Hg}$ in the surface sediment (FABBRI et al., 1998). Deep sediment profiles show an $\mathrm{Hg}$ concentration peak $\left(40 \mu \mathrm{g} \mathrm{g}^{-1}\right)$ at 3-7 $\mathrm{cm}$ depth, which matches the time of industrial site conversion (MATTEUCCI et al., 2005). COVELLI et al. (2011) found that $\mathrm{Hg}^{0}$ represents the dominant fraction $(87.5 \%)$ in the sediment. Differences in mercury speciation across the lagoon might reflect different biogeochemical cycling (TROMBINI et al., 2003). MeHg concentrations in sediments (0.13$44.6 \mathrm{ng} \mathrm{g}^{-1}$ ) represent a small fraction of $\mathrm{THg}$ (up to $0.07 \%$ in surface sediments) which TROMBINI et al. (2003) attributed to bacterial detoxification; this value is smaller than the characteristic $\sim 0.5 \%$ for estuarine environments (COVELLI et al., 2011). MeHg porewaters concentrations show the highest values in the first centimetre (COVELLI et al., 2011), suggesting that methylation occurs in a thin layer, close to sediment-water interface. Calculated distribution coefficient $\mathrm{K}_{\mathrm{D}}$ for $\mathrm{THg}$ $\left(\log K_{D} 6.27\right)$ is almost constant with depth, indicating a steady-state equilibrium between two phases that controls $\mathrm{THg}$ distribution in the presence of sulphide (COVELLI et al., 2011). Mercury is still present in surface sediments and can pose a "time bomb" for the ecosystem (FABBRI et al., 1998).

\section{Venice Lagoon}

Venice Lagoon is the largest lagoon in the Mediterranean. Two chlor-alkali plants (19511988) were the main contributors to $\mathrm{Hg}$ con- tamination (GUÉDRON et al., 2012) with an estimated discharge of 100-300 t (BLOOM et al., 2004). In the most contaminated areas, $\mathrm{THg}$ in water is up to $201 \mathrm{ng} \mathrm{L}^{-1}$. Dissolved $\mathrm{THg}$ accounts for $4-39 \%$ of $\mathrm{THg}$, while dissolved $\mathrm{MeHg}$ represents up to $2.8 \%$ of $\mathrm{THg}$ (BLOOM et al., 2004). Mercury distribution in SPM shows weak concentration gradient from the northern $\left(1.17 \mu \mathrm{g} \mathrm{g}^{-1}\right)$ to the southern part $\left(0.76 \mu \mathrm{g} \mathrm{g}^{-1}\right)$ of the lagoon. The highest value $\left(3.26 \mu \mathrm{g} \mathrm{g}^{-1}\right)$ is found in the industrial canal (BLOOM et al., 2004). In surface sediments, $\mathrm{THg}$ has slightly higher values, while $\mathrm{MeHg}$ shows 4-10 times higher values in SPM $\left(\log \mathrm{K}_{\mathrm{D}}\right.$ 6.89) (BLOOM et al., 2004). Therefore, tidal flushing may enhance dispersal of particulate $\mathrm{MeHg}$ throughout the lagoon (GUÉDRON et al., 2012). MeHg in sediments never excided $0.45 \%$ of $\mathrm{THg}$; it acts as a net source of $\mathrm{MeHg}$ for SPM and a sink for particulate inorganic Hg (GUÉDRON et al., 2012). MeHg is highly correlated to $\mathrm{THg}$ and organic matter, suggesting their influence on methylation in the sediments (GUÉDRON et al., 2012). Specific methylation rates are usually the highest in the surface layers (up to $5.5 \% \mathrm{~d}^{-1}$ ) (KIM et al., 2011). GUÉDRON et al. (2012) found three MeHg peaks in sediment porewaters at the depths corresponding to the reduction of $\mathrm{Fe}$ oxides, oxidation of fresh OM, and sulphate reduction. Their results indicate that the Fe reduction zone is the most important source of $\mathrm{MeHg}$ for the water column. High molecular diffusion fluxes (9.46 and 1.09 $\mathrm{ng} \mathrm{\textrm {m } ^ { - 2 }} \mathrm{d}^{-1}$ for $\mathrm{Hg}(\mathrm{II})$ and $\mathrm{MeHg}$, respectively) (GUÉDRON et al., 2012) indicate that open lagoon sediments may represent an important source of dissolved MeHg (GUÉDRON et al., 2012). BLOOM et al. (2004) estimated $1.1 \mathrm{t} \mathrm{a}^{-1} \mathrm{Hg}$ flux into the Adriatic Sea, which makes the Venice Lagoon one of the biggest exporters of $\mathrm{Hg}$ to the Adriatic Sea.

\section{Marano and Grado Lagoon}

The Grado-Marano wetland system consists of the western, shallow Grado sector, and eastern Marano sector, which is largely covered in saltmarshes (FONTOLAN et al., 2012). Source of $\mathrm{Hg}$ pollution was a chlor-alkali plant (1949-1984) and $186 \mathrm{t}$ of $\mathrm{Hg}$ were deposited 
into the lagoons (ACQUAVITA et al., 2012). $\mathrm{Hg}^{0}$ from chlor-alkali plant is the main fraction in the Marano sector and sulphide-bound $\mathrm{Hg}$ from Isonzo River in the Grado sector (ACQUAVITA et al., 2012). Presence of $\mathrm{Hg}$ from the Isonzo River is observed through the $\mathrm{THg}$ gradient in surface sediments; from $11 \mu \mathrm{g} \mathrm{g}^{-1}$ in Grado to $1 \mu \mathrm{g} \mathrm{g}^{-1}$ in Marano (COVELLI et al., 2011). The highest $\mathrm{THg}$ concentrations are usually found in the top core sections with almost exponential decrease from about $30 \mathrm{~cm}$ depth to the basal core where background values are found (average $0.13 \mu \mathrm{g}$ $\mathrm{g}^{-1}$ ), indicating recent contamination (COVELLI et al., 2012). $\mathrm{MeHg}$ in sediments accounts for up to $0.2 \%$ of THg (COVELLI et al., 2008). MeHg is the highest in surface sediments (up to $21.9 \mathrm{ng}$ $\left.\mathrm{g}^{-1}\right)$ and decreases with depth almost exponentially, suggesting that $\mathrm{MeHg}$ accumulation and production occur just below the sediment-water interface (COVELLI et al., 2008). MeHg accounts for only $0.03 \%$ of $\mathrm{THg}$ in SPM, and therefore additional $\mathrm{MeHg}$ must be produced by microbial activity (COVELLI et al., 2008). The average concentrations of $\mathrm{THg}$ and $\mathrm{MeHg}$ in porewaters

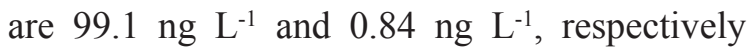
(EMILI et al., 2012). COVELLI et al. (2008) found that THg in porewaters of the Grado sector increased with depth which could be due to $\mathrm{Hg}$ scavenging by soluble $\mathrm{Fe}$ and $\mathrm{Mn}$ (oxy)hydroxides at low oxygen and sulphide conditions. The log $\mathrm{K}_{\mathrm{D}}$ for $\mathrm{MeHg}$ is $\sim 3$ (COVELLI et al., 2008; HINES et al., 2012), indicating low affinity for sediment matter. Diffusive fluxes range from -37-570 $\mathrm{ng}$ $\mathrm{m}^{-2} \mathrm{~d}^{-1}$ for THg and from -5.5-16.3 $\mathrm{ng} \mathrm{m}^{-2} \mathrm{~d}^{-1}$ for $\mathrm{MeHg}$ (EMILI et al., 2012). High benthic fluxes (2.54-41.1 $\mu \mathrm{g} \mathrm{m}^{-2} \mathrm{~d}^{-1}$ for THg and 0.08-2.29 $\mu \mathrm{g}$ $\mathrm{m}^{-2} \mathrm{~d}^{-1}$ for $\mathrm{MeHg}$ ) (EMILI et al., 2012) suggest that sediments in the lagoon are an important source of mercury for the water column (COVELLI et al., 2008, 2011). Sulphate reducing bacteria (SRB) are mostly responsible for $\mathrm{Hg}$ methylation and the oxidative demethylation of $\mathrm{MeHg}$ (HINES et al., 2012). Demethylation rates are $\sim 10$ times higher than methylation rates (HINES et al., 2012), which might decrease the rate of $\mathrm{MeHg}$ accumulation.

\section{The Gulf of Trieste}

The Gulf of Trieste is a shallow water basin (up to $\sim 25 \mathrm{~m}$ ) located in the northeastern part of the Adriatic Sea. Mercury contamination originates from the Isonzo River, which drains the cinnabar deposits from the world's second largest $\mathrm{Hg}$ mine in Idrija, Slovenia (HORVAT et al., 1999). Over $5 \times 10^{9} \mathrm{~kg}$ of $\mathrm{Hg}$ ore was excavated and $73 \%$ (estimation) of the mercury was recovered (COVELLI et al., 1999). THg in the surface water layer of the central part of the Gulf is relatively low, but higher concentrations (up to $64.5 \mathrm{ng} \mathrm{L}^{-1}$ ) are found in the area in front of the Isonzo River mouth as a consequence of sediment re-suspension (Fig. 7B) (FAGANELI et al., 2003). $\mathrm{MeHg}$ shows low surface values and higher bottom values (up to $126 \mathrm{pg} \mathrm{L}^{-1}$ ) (FAGANELI et al., 2003). In the Gulf waters, THg is highly associated with SPM $\left(\log \mathrm{K}_{\mathrm{D}} 5-6\right)$. Particulate $\mathrm{Hg}$ accounts for $<10 \%$ to $>90 \%$ of $\mathrm{THg}$ present in the seawater, with the highest values found in the surface layer near the Isonzo River outflow (FAGANELI et al., 2003). During high river floods, concentrations of particulate $\mathrm{Hg}$ in front of the river outflow are 5-40 times higher than during low river discharge (COVELLI et al., 2007). Low log $\mathrm{K}_{\mathrm{D}}$ for $\mathrm{MeHg}(<1)$ indicates much weaker binding of MeHg to SPM (FAGANELI et al., 2003; HORVAT et al., 1999). THg in sediments and short cores $(0-10 \mathrm{~cm})$ shows homogeneous distribution of mercury (HORVAT et al., 1999). On the contrary, cores below $100 \mathrm{~cm}$ depth have $\mathrm{THg}$ concentrations around the background values $\left(0.17 \mu \mathrm{g} \mathrm{g}^{-1}\right)$ while the sudden increase is observed toward the surface layers (COVELLI et al., 2001, 2006a). $\mathrm{MeHg}$ concentrations in surface sediments (0.2-60.1 ng $\mathrm{g}^{-1}$ ) correspond to $0.3-1.0 \%$ of $\mathrm{THg}$. This value increases with the distance from the river mouth (HORVAT et al., 1999), suggesting that coastal areas where methylation occurs are not necessarily areas with the highest $\mathrm{THg}$ concentrations (COVELLI et al., 2001). Methylation activity in sediments (up to $2.0 \% \mathrm{~d}^{-1}$ ) decreases with depth, indicating that recent sediment could represent a source of $\mathrm{MeHg}$ for the water column (COVELLI et al., 1999; HORVAT et al., 1999). SRB mediated oxidative demethylation is mostly active in the 
uppermost layer of sediment, while reductive demethylation is negligible $(<10 \%)$ (HINES et al., 2000). THg concentration in porewaters is relatively high $\left(107 \mathrm{ng} \mathrm{L}^{-1}\right)$. This elevated value could be related to the solubility changes of $\mathrm{Fe}$ and Mn (oxy)hydroxides (COVELLI et al., 1999), similarly as in the Marano and Grado Lagoon. Diffusive fluxes range from $-2.12-41.3 \mathrm{ng} \mathrm{m}^{-2}$ $\mathrm{d}^{-1}$ and from -1.77-4.39 $\mathrm{ng} \mathrm{m}^{-2} \mathrm{~d}^{-1}$ for THg and $\mathrm{MeHg}$, respectively (COVELLI et al., 1999). Benthic fluxes (71-665 $\mathrm{ng} \mathrm{m}^{-2} \mathrm{~d}^{-1}$ for $\mathrm{THg}$ and 238$577 \mathrm{ng} \mathrm{m}^{-2} \mathrm{~d}^{-1}$ for MeHg) (EMILI et al., 2014) are much lower than those observed in the Marano and Grado Lagoon. Dissolved Hg in the benthic chamber water is dominantly in the methylated form during anoxic phase (EMILI et al., 2011, 2014). About $75 \%$ of THg is buried in the sediment and the rest is recycled at the sediment-water interface. Methylated form represents $\sim 23 \%$ of recycled THg (COVELLI et al., 1999), making the Gulf of Trieste an efficient trap for $\mathrm{THg}$ and a source of MeHg to the bottom waters (HINES et al., 2000).

\section{Kaštela Bay}

The Bay of Kaštela is the largest bay in the central Adriatic. It is an area of high primary production due to the weathering of nutrients from surrounding fields (ZVONARIĆ, 1991). The Bay was contaminated with at least $150 \mathrm{t}$ of $\mathrm{Hg}$ (estimated) originating from a chlor-alkali plant (1950-1990) (KWOKAL et al., 2002; ZVONARIĆ, 1991). Concentrations of $\mathrm{THg}$ in surface waters close to the chlor-alkali plant are high (up to 145 ng $\mathrm{L}^{-1}$ ). Even higher concentrations in bottom waters suggest re-suspension from sediments or partial dissolution (KWOKAL et al., 2002). The lowest $\mathrm{THg}$ concentrations are found at the exit of the bay (Fig. 7B) (HORVAT et al., 2003). Approximately $70-100 \%$ of $\mathrm{THg}$ in water column is associated with SPM (KWOKAL et al., 2002). $\mathrm{MeHg}$ concentrations in waters are in the range 0.01-0.04 ng L-1 (HORVAT et al., 2003). Percentages of dissolved $\mathrm{MeHg}$ vary, but the highest value $(46.8 \%)$ is found near the chlor-alkali plant (HORVAT et al., 2003). Elevated THg concentration in the sediment (Fig. 7A) can be explained by the fact that the chlor-alkali plant discharged $\sim 1 \mathrm{t} \mathrm{a}^{-1}$ of $\mathrm{Hg}^{0}$ until 1990 (KWOKAL et al., 2002). Very high concentrations are also found at up to $0.5 \mathrm{~m}$ depth (MIKAC et al., 2006). Depth distribution of THg is irregular near the chlor-alkali plant due to human perturbation of sediments, which are a mixture of coal ash and natural sediments (MIKAC et al., 2006). MeHg concentrations are typical for slightly to highly contaminated estuarine sediments (KWOKAL et al., 2002) but the $\mathrm{MeHg} / \mathrm{THg}$ ratio in sediments is rather low $(<0.18 \%)$. Even though the sediments are highly anoxic, this indicates that requirements for in situ methylation do not exist (KWOKAL et al., 2002). Therefore, most of $\mathrm{Hg}$ remains in the discharged form. $\mathrm{Hg}^{0}$ is probably the only stable phase or perhaps $\mathrm{Hg}$ is bound to sulphide or sulphydryl groups (KWOKAL et al., 2002).

\section{Vlora Bay}

The Bay of Vlora represents the natural boundary between the Ionian and the Adriatic Sea. Pollution arises from the use of metallic $\mathrm{Hg}$ for chlor-alkali electrolysis. During factory operation (1976-1992), liquid wastewaters containing $1.1 \mathrm{mg} \mathrm{L}^{-1}$ of mercury was discharged directly into the sea (CULLAJ et al., 2004). It has been estimated that about $65 \mathrm{t}$ of mercury had been discharged in the environment from 1977-1983 (CULLAJ et al., 2004). In the sediment, mercury can reach up to $0.92 \mu \mathrm{g} \mathrm{g}^{-1}$ (Fig. 7A). Pollution zone is not restricted to the plant area: CULLAJ et al. (2004) observed $\mathrm{Hg}$ relocation to the SW part of the Bay of Vlora and attributed it to hydrological factors. These factors do not favour $\mathrm{Hg}$ transportation to the open sea due to restricted communication. The biggest contributor to $\mathrm{Hg}$ transport is the fine sediment fraction. Mercury is mostly present in the fine fraction of the sediment $\left(<63 \mu \mathrm{m} ; 0.60 \mu \mathrm{g} \mathrm{g}^{-1}\right)$, contrary to the coarse fraction $(<250 \mu \mathrm{m})$ that contains only $0.23 \mu \mathrm{g} \mathrm{g}^{-1}$ of mercury (CULLAJ et al., 2004). $\mathrm{THg}$ concentrations in seawaters are high (Fig. 7B) and the highest values are found in front of the chlor-alkali plant (QARRI et al., 2014; LAZO \& CULLAJ, 2002). Organic mercury fraction represents $50-59 \%$ of THg (LAZO \& CULLAJ, 2002). Although the mercury-polluted soil was encap- 
sulated in 2011, previous emissions of metallic mercury can still be observed in the sediments of the Bay of Vlora due to soil erosion (QARRI et al., 2014).

\section{Krka River estuary}

The Krka river estuary is a stratified estuary located in the central part of the Eastern Adriatic coast. The biggest contamination sources are industrial and municipal wastewaters from the town of Šibenik. In comparison with other sites, this region can be characterised as relatively pristine (KWOKAL et al., 2002). THg concentrations in the sediment of Krka river estuary are generally low (Fig. 7A). Slightly elevated values are found in the vicinity of urbanized areas near the city of Šibenik. MeHg has the lowest values among all case studies (0.50-2.96 $\left.\mathrm{ng} \mathrm{g}^{-1}\right)$ (KWOKAL et al., 2002). In the water, MeHg values are in the range of 0.03-0.14 $\mathrm{ng} \mathrm{L}^{-1}$. The highest values are found within the freshwater-seawater interface (FSI) which can be explained by the association of $\mathrm{Hg}$ with mineral particles and dissolved organic compounds in the FSI (KWOKAL \& LOVRIĆ, 2006). Presence of hydrophobic heterodispersed substances provides evidence that $\mathrm{Hg}$ is bound to hydrophobic particulate matter (BILINSKI et al., 2000). THg concentrations in the water column (up to $12.5 \mathrm{ng} \mathrm{L}^{-1}$ ) vary with depth and within each layer. THg maximum can be found in freshwater, at the FSI, below the FSI, or not at all (BILINSKI et al., 2000). Input of atmospheric mercury into the estuary via precipitation can be observed through the $\mathrm{Hg}$ maximum in the freshwater layer. Strong winds can affect mercury concentration in the water column. During Bura wind (NE), mercury is transported to the sediments, resulting in low water column concentrations $\left(<1 \mathrm{ng} \mathrm{L}^{-1}\right)$. On the contrary, during Jugo wind (SE) the outflow of brackish water decreases and water current in the marine layer goes from the sediment to the FSI (BILINSKI et al., 2000; KWOKAL \& LOVRIĆ, 2006).

\section{ROLE OF PLANKTON IN MERCURY BIOGEOCHEMISTRY}

In the Mediterranean Sea, several fish species (STORELLI et al., 1998) show elevated mercury levels compared to the same species in the Atlantic Ocean, although $\mathrm{THg}$ concentrations in these two water masses are comparable (ŽAGAR et al., 2013). The hypothesis that above average natural environmental levels in the Mediterranean are responsible conflicts with measured concentrations and distribution of mercury in the Mediterranean Sea (HORVAT et al., 2003). In the open sea, oligotrophic environment plays an important role in mercury biogeochemistry. With relatively few nutrients, low primary productivity and low phytoplankton biomass, the Mediterranean Sea is classified as oligotrophic (UNEP, 2012). Oligotrophic conditions are characterised by higher proportions of dissolved rather than particulate carbon (ŠOLIĆ et al., 2010). In oligotrophic systems, picoplankton dominates the biomass and the production (ŠOLIĆ et al., 2010). Heterotrophic picoplankton (mostly heterotrophic bacteria) and autotrophic picoplankton (Prochlorococcus, Synechococcus and picoeukaryotes) represent the major components of the marine picoplankton community, especially in oligotrophic areas such as the Adriatic Sea (ŠOLIĆ et al., 2010, 2016). Vertical profiles of methylated mercury species show nutrient-like patterns within the biologically active zone (COSSA et al., 2009). HEIMBÜRGER et al. (2010) showed that $\mathrm{Hg}$ methylation was promoted during oligotrophic periods in the hypoxic water layer when primary production was dominated by nano- and picophytoplankton. These microorganisms may favour $\mathrm{Hg}$ methylation due to their great surface/ volume ratio, which enables efficient accumulation of particle-reactive trace metals. Two $\mathrm{MeHg}$ maxima exist in the water column in which phytoplankton-derived dissolved organic carbon and particulate organic carbon are the main bacterial carbon sources in the photic and aphotic zone, respectively (HEIMBÜRGER et al., 2010). Elevated $\mathrm{MeHg}$ concentrations in the surface and bottom water in the southern Adriatic Sea are probably the result of similar biological processes (KOT- 
NIK et al., 2015). Concentrations of $\mathrm{MeHg}$ in the seawater are correlated with chlorophyll $a$ and oxygen concentrations, emphasising the role of planktonic production and mercury regeneration through methylation/demethylation processes (KOTNIK et al., 2013, 2015). Also higher temperature of the deep waters may promote microbiologically mediated formation of $\mathrm{MeHg}$ in the water and sediment (COSSA \& COQUERY, 2005). The structure of the microbial food web and the microbial role in biogeochemical processes in aquatic environments can vary considerably and depends on environmental trophic status (ŠOLIĆ et al., 2010).

\section{CONCLUSIONS}

The Adriatic Sea exhibits the complexity of mercury cycling and the importance of the anthropogenic influence, especially in coastal areas. Mercury in the Adriatic seawaters and sediments shows a concentration gradient from the north to the south; the highest $\mathrm{THg}$ concentrations in the whole Mediterranean Sea are found in the northern Adriatic Sea. Changes in concentrations of mercury species with time can be observed in both the Mediterranean and the Adriatic Sea, especially for $\mathrm{THg}$ and $\mathrm{RHg}$ concentrations in seawater. These changes are probably connected to the closure of the Idrija mine and chlor-alkali plants, or possible sample contamination in the past. The trend cannot be accurately assessed for other $\mathrm{Hg}$ fractions in seawater because most of them were not measured prior to 1990s. In the sediments, THg concentrations are comparable with the newer results. However, THg values in the central and southern Adriatic sediments, and $\mathrm{Hg}$ speciation in sediments are too scarce to comprehensively assess $\mathrm{Hg}$ biogeochemistry in the Adriatic sediments. From the available data, it is evident that $\mathrm{Hg}$ contamination is mostly limited to the surficial sediments, while concentrations in the deeper cores are near background values.

Although the waters of the northern Adriatic Sea, along with the coastal lagoons, have the highest $\mathrm{THg}$ values in the whole of Adriatic, this does not reflect the distribution of $\mathrm{MeHg}$.
Recent data indicate that $\mathrm{MeHg}$ production in the water column is the major source of $\mathrm{MeHg}$ in the Adriatic waters (especially in the southern Adriatic Pit), and that diffusion from the sediments cannot account for all observed $\mathrm{MeHg}$. This indicates the important role of plankton in the methylation processes. However, in the coastal areas, bacterial methylation in the sediments plays an important role. Mercury methylation rates in the sediments of the Gulf of Trieste and the Venice lagoon are the highest in the whole Adriatic Sea. Water circulation can transfer produced $\mathrm{MeHg}$ and disperse it into the open Adriatic.

The spatial distribution of $\mathrm{Hg}$ in the marine environment depends on the seawater circulation, and biological and geological factors. These factors influence the transformations of $\mathrm{Hg}$, leading to production of substantial amounts of $\mathrm{MeHg}$, which can represent a major ecological burden, especially to the marine biota in the Adriatic Sea. In order to fully assess the impact of contamination in the Adriatic Sea, future research needs to focus on parameters that control $\mathrm{Hg}$ transformations in the environment. Thorough determination and speciation of $\mathrm{Hg}$ in all environmental compartments, together with the identification of specific biological (microbial methylation/demethylation), physical (diffusion, solubility, volatility) and chemical processes (redox, radical and photoreactions, methylation/demethylation, stable isotopes fractionation), could provide a better insight into $\mathrm{Hg}$ biogeochemistry and the susceptibility of the Adriatic Sea to contamination.

\section{ACKNOWLEDGEMENTS}

The authors would like to thank Dr. Suzana ŽIŽEK for grammar corrections. The authors acknowledge the funding from the Slovenian Research Agency through the programme P1-0143 and project PR-06179, the European FP7 GMOS project, and the Croatian Science Foundation for financial support of the research project MICROGLOB (IP-2014-09-4143). 


\section{REFERENCES}

ACQUAVITA, A., S. COVELLI, A. EMILI, D. BERTO, J. FAGANELI, M. GIANI, M. HORVAT, N. KORON \& F. RAMPAZZO. 2012. Mercury in the sediments of the Marano and Grado Lagoon (northern Adriatic Sea): Sources, distribution and speciation. Est. Coast. Shelf Sci., 113: 20-31.

AMAP/UNEP. 2013. Technical Background Report for the Global Mercury Assessment 2013. UNEP Chemicals Branch, Geneva, Switzerland, $159 \mathrm{pp}$.

ANCONELLI, M.T., C. BALDRATI \& W. VANDINI. 1980. Studio composito sull'inquinamento da mercurio ed altri oligoelementi nelle valli ravennati (piallasse) (Composite study on pollution by mercury and other trace elements in Ravenna Lagoon (Piallasse)). Acqua-Aria, 10: 1323-1331.

ARTEGIANI, A., D. BREGANT, E. PASCHINI, N PINARDI, F. RAICICH \& A. RUSSO. 1997. The Adriatic Sea general circulation. Part I. Airsea interactions and water mass structure. J. Phys. Oceanogr., 27: 1492-1514.

BENSI, M., V. CARDIN \& A. RUBINO. 2014. Thermohaline Variability and Mesoscale Dynamics Observed at the Deep-Ocean Observatory E2M3A in the Southern Adriatic Sea. In: G.L.E. Borzelli, M. Gačić, P. Lionello \& P. Malanotte-Rizzoli (Editors). The Mediterranean Sea: Temporal Variability and Spatial Patterns, Geophysical Monograph Series. John Wiley \& Sons, Inc., Oxford, UK, pp. 139-155.

BERNHARD, M. 1988. Mercury in the Mediterranean. UNEP, Nairobi, Kenia, 141 pp.

BERTO, D., M. GIANI, S. COVELLI, R. BOSCOLO, M. CORNELLO, S. MACCHIA \& M. MASSIRONI. 2006. Mercury in sediments and Nassarius reticulatus (Gastropoda Prosobranchia) in the southern Venice Lagoon. Sci. Total Environ., 368: 298-305.

BILINSKI, H., Ž. KWOKAL, M. PLAVŠIĆ, M. WRISCHER \& M. BRANICA. 2000. Mercury distribution in the water column of the stratified Krka river estuary (Croatia): Importance of natural organic matter and of strong winds. Water Res., 34(7): 2001-2010.
BLOOM, N.S., L.M. MORETTO, P. SCOPECE \& P UGO. 2004. Seasonal cycling of mercury and monomethyl mercury in the Venice Lagoon (Italy). Mar. Chem., 91: 85-99.

BOWMAN, K. L., C. R. HAMMERSCHMIDT, C. H. LAMBORG \& G. SWARR. 2015. Mercury in the North Atlantic Ocean: The U.S. GEOTRACES zonal and meridional sections. Deep Sea Res. II, 116: 251-261.

CHEN, C. Y., C. T. DRISCOLL, K. F. LAMBERT, R. P. MASON \& E. M. SUNDERLAND. 2016. Connecting mercury science to policy: from sources to seafood. Res. Environ. Health, 31(1): 17-20.

CIVITARESE, G. \& M. GAČIĆ. 2001. Had the Eastern Mediterranean Transient an impact on the new production in the southern Adriatic? Geophys. Res. Lett., 28: 1627-1630.

COMBI, T., S. MISEROCCHI, L. LANGONE \& R. GUERRA. 2016. Polychlorinated biphenyls (PCBs) in sediments from the western Adriatic Sea: Sources, historical trends and inventories. Sci. Total Environ., 562: 580-587.

COSSA, D., J.-M. MARTIN, K. TAKAYANAGI \& J. SANJUAN. 1997. The distribution and cycling of mercury species in the western Mediterranean. Deep-Sea Res. Part II, 44: 721-740.

COSSA, D. \& M. COQUERY. 2005. The Mediterranean Mercury Anomaly, a Geochemical or a Biologocal Issue. In: A. Saliot (Editor). The Mediterranean Sea; The Handbook of Environmental Chemistry, 5K. Springer-Verlag, Berlin, Germany, pp. 177-208.

COSSA, D., B. AVERTY \& N. PIRRONE. 2009. The origin of methylmercury in open Mediterranean waters. Limnol. Oceanogr., 54(3): 837-844.

COSSA, D., L.-E. HEIMBÜRGER, D. LANNUZEL, S. R. RINTOUL, E. C. V. BUTLER, A. R. BOWIE, B. AVERTY, R. J. WATSON \& T. REMENYI. 2011. Mercury in the Southern Ocean. Geochim. Cosmochim. Ac., 75: 4037-4052.

COSTA, M. \& P. S. LISS. 1999. Photoreduction of mercury in sea water and its possible implications for $\mathrm{Hg}^{0}$ air-sea fluxes. Mar. Chem., 68: 87-95. 
COVELLI, S., J. FAGANELI, M. HORVAT \& A. BRAMBATI. 1999. Pore water Distribution and Benthic Flux Measurements of Mercury and Methylmercury in the Gulf of Trieste (Northern Adriatic Sea). Est. Coast. Shelf Sci., 48: 415-428.

COVELLI, S., J. FAGANELI, M. HORVAT \& A. BRAMBATI. 2001. Mercury contamination of coastal sediments as the result of long-term cinnabar mining activity (Gulf of Trieste, northern Adriatic Sea). Appl. Geochem., 16: 541-558.

COVELli, S., G. FONTOLAN, J. FAGANELI \& N. OGRINC. 2006a. Anthropogenic markers in the Holocene stratigraphic sequence of the Gulf of Trieste (northern Adriatic Sea). Mar. Geol., 230: 29-51.

COVElli, S., R. PIANI, J. KOTNIK, M. HORVAT, J. FAGANELI \& A. BRAMBATI. 2006b. Behaviour of $\mathrm{Hg}$ species in a microtidal deltaic system: The Isonzo River mouth (northern Adriatic Sea). Sci. Total Environ., 368: 210-223.

COVElli, S., R. PIANI, A. ACQUAVITA, S. PREDONZANI \& J. FAGANELI. 2007. Transport and dispersion of particulate $\mathrm{Hg}$ associated with a river plume in coastal Northern Adriatic environments. Mar. Pollut. Bull., 55: 436450.

COVELli, S., J. FAGANELI, C. DE VITTOR, S. PREDONZANI, A. ACQUAVITA \& M. HORVAT. 2008. Benthic fluxes of mercury species in a lagoon environment (Grado Lagoon, Northern Adriatic Sea, Italy). Appl. Geochem., 23: 529-546.

COVELlI, S., A. EMILI, A. ACQUAVITA, N. KORON \& J. FAGANELI. 2011. Benthic biogeochemical cycling of mercury in two contaminated northern Adriatic coastal lagoons. Cont. Shelf Res., 31: 1777-1789.

COVELLI, S., L. LANGONE, A. ACQUAVITA, R. PIANI \& A. EMILI. 2012. Historical flux of mercury associated with mining and industrial sources in the Marano and Grado Lagoon (northern Adriatic Sea). Estuar. Coast. Shelf Sci., 113: 7-19.

CULLAJ, A., P. LAZO \& B. BARAJ. 2004. Investigation of Mercury Contamination in Vlora Bay (Albania). RMZ-M\&G, 51: 58-62.

DONAZZOLO, R., O.H. MERLIN, L.M. VITTURI, A.A.
ORIO, B. PAVONI, G. PERIN \& S. RABITTI. 1981. Heavy metal contamination in surface sediments from the Gulf of Venice, Italy. Mar. Pollut. Bull., 12: 417-425.

DONAZZOLO, R., O. HIEKE MERLIN, L. MENEGAZZO VITTURI \& B. PAVONI. 1984. Heavy metal content and lithological properties of recent sediments in the Northern Adriatic. Mar. Pollut. Bull., 15: 93-101.

DRISCOLL, C. T., R. P. MASON, H. M. CHAN, D. J. JACOB \& N. PIRRONE. 2013. Mercury as a global pollutant: Sources, pathways, and effects. Environ. Sci. Technol., 47: 49674983.

EMILI, A., N. KORON, S. COVELLI, J. FAGANELI, A. ACQUAVITA, S. PREDONZANI \& C. DE VITTOR. 2011. Does anoxia affect mercury cycling at the sediment-water interface in the Gulf of Trieste (northern Adriatic Sea)? Incubation experiments using benthic flux chambers. Appl. Geochem., 26: 194-204.

EMILI, A., A. ACQUAVITA, N. KORON, S. COVELLI, J. FAGANELI, M. HORVAT, S. ŽIŽEK \& V. FAJON. 2012. Benthic flux measurements of $\mathrm{Hg}$ species in a northern Adriatic lagoon environment (Marano and Grado Lagoon, Italy). Estuar. Coast. Shelf Sci., 113: 71-84.

EMILI, A., L. CARRASCO, A. ACQUAVITA \& S. COVELLI. 2014. A laboratory-incubated redox oscillation experiment to investigate $\mathrm{Hg}$ fluxes from highly contaminated coastal marine sediments (Gulf of Trieste, Northern Adriatic Sea). Environ. Sci. Pollut. Res., 21: 4124-4133.

FABBRI, D., O. FELISATTI, M. LOMBARDO, C. TROMBINI \& I. VASSURA. 1998. The Lagoon of Ravenna (Italy): Characterisation of mercury-contaminated sediments. Sci. Total Environ., 213: 121-128.

FABBRI, D., G. GABBIANELLI, C. LOCATELLI, D. LUBRANO, C. TROMBINI \& I. VASSURA. 2001. Distribution of mercury and other heavy metals in core sediments of the northern Adriatic Sea. Water Air Soil Pollut., 129: 143-153.

FAGANELI, J., M. HORVAT, S. COVELLI, V. FAJON, M. LOGAR, L. LIPEJ \& B. CERMELJ. 2003. Mercury and methylmercury in the Gulf of Trieste 
(northern Adriatic Sea). Sci. Total Environ., 304: 315-326.

FAGANELI, J., M.E. HINES, S. COVELLI, A. EMILI \& M. GIANI. 2012. Mercury in lagoons: An overview of the importance of the link between geochemistry and biology. Estuar. Coast. Shelf Sci., 113: 126-132.

FANTOZZI, L., R. FERRARA, F.P. FRONTINI \& F. DINI. 2009. Dissolved gaseous mercury production in the dark: Evidence for the fundamental role of bacteria in different types of Mediterranean water bodies. Sci. Total Environ., 407: 917-924.

FANTOZZI, L., G. MANCA, I. AMMOSCATO, N. PIRRONE \& F. SPROVIERI. 2013. The cycling and sea-air exchange of mercury in the waters of the Eastern Mediterranean during the 2010 MED-OCEANOR cruise campaign. Sci. Total Environ., 448: 151-162.

FERRARA, R., A. SERITTI, C. BARGHIANI \& A. PETROSINO. 1986. Mercury levels in the dissolved and particulate fractions of the Tyrrhenian Sea. Mar. Chem., 18:227-232.

FERRARA, R. \& B.E. MASERTI. 1992. Mercury concentration in the water, particulate matter, plankton and sediment of the Adriatic Sea. Mar. Chem., 38: 237-249.

FERRARA, R., B. MAZZOLAI, E. LANZILLOTTA, E. NUICARO \& N. PIRRONE. 2000. Volcanoes as emission sources of atmospheric mercury in the Mediterranean basin. Sci. Total Environ., 259: 115-121.

FITZGERALD, W. F. \& C. H. LAMBORG. 2003. Geochemistry of Mercury in the Environment. In: K.K. Turekian \& H.D. Holland (Editors). Treatise on Geochemistry. Elsevier, Oxford, UK, pp. 107-148.

FITZGERALD, W. F., C. H. LAMBORG \& C. R. HAMMERSCHMIDT. 2007. Marine biogeochemical cycling of mercury. Chem. Rev., 107: 641662.

FONTOLAN, G., S. PILLON, A. BEZZI, R. VILLALTA, M. LIPIZER, A. TRICHES \& A. D'AIETTI. 2012. Human impact and the historical transformation of saltmarshes in the Marano and Grado Lagoon, northern Adriatic Sea. Estuar. Coast. Shelf Sci., 113: 41-56.

FOWLER, S.W., T.F. HAMILTON, M. COQUERY, J.-P.
VILLNEUVE \& M. HORVAT. 1999. Concentration of selected trace elements and PCBs in sediments from the Adriatic Sea. In: T.S. Hopkins, A. Artegiani, G. Cauwet, D. Degobbis \& A. Malej (Editors). Workshop on "Physical and biogeochemical processes in Adriatic Sea", Portonovo, Italy, 23 to 27 April 1996. European Commission, Luxembourg, Luxembourg, pp. 611-625.

FRASCARI, F., M. FRIGNANI, S. GUERZONI \& M. RAVAIOLI. 1988. Sediments and Pollution in the Northern Adriatic Sea. Ann. N. Y. Acad. Sci., 534: 1000-1020.

FRIGNANI, M., F. FRASCARI, P. GIORDANI, S. GUERZONI, F. MARABINI \& R. POLETTI. 1976. Heavy Metal distribution related to sedimentological features in bottom sediments of the Adriatic Sea between Ancona and the Po river delta. In: III ${ }^{\mathrm{es}}$ Journée Étude Pollutions. CIESM, Split, Croatia, pp. 81-82.

FRIGNANI, M., F. FRASCARI, G. QUARANTOTTO \& R. POLETTI. 1978. Trace heavy metals in Adriatic Sea sediments off the Italian coast from Pesaro to the Po delta. Giorn. Geol., 43: 27-45.

FRIGNANI, M., L. LANGONE, M. RAVAIOLI, D. SORGENTE, F. ALVISI \& S. ALBERTAZZI. 2005. Finesediment mass balance in the western Adriatic continental shelf over a century time scale. Mar. Geol., 222-223: 113-133.

GÅRDFELDT, K., X. FENG, J. SOMMAR \& O. LINDQVIST. 2001. Total gaseous mercury exchange between air and water at river and sea surfaces in Swedish coastal regions. Atmos. Environ., 35: 3027-3038.

GÅRDFELDT, K., J. SOMMAR, R. FERRARA, C. CECCARINI, E. LANZILLOTTA, J. MUNTHE, I. WANGBERG, O. LINDQVIST, N. PIRRONE, F. SPROVIERI, E. PESENTI \& D. STROMBERG. 2003. Evasion of mercury from coastal and open waters of the Atlantic Ocean and the Mediterranean Sea. Atmos. Environ., 37: S73-S84.

GIANI, M., M. GABELLINI, D. PELLEGRINI, S. COSTANTIN, E. BECCALONI \& R. GIORDANO. 1994. Concentration and partitioning of $\mathrm{Hg}, \mathrm{Cr}$ and $\mathrm{Pb}$ in sediments of dredge and disposal sites of the northern Adriatic Sea. Sci. Total Environ., 158: 97-112. 
GIANI, M., F. RAMPAZZO, D. BERTO, C. MAGGI, A. MAO, M. HORVAT, A. EMILI \& S. COVELLI. 2012. Bioaccumulation of mercury in reared and wild Ruditapes philippinarum of a Mediterranean lagoon. Estuar. Coast. Shelf Sci., 113: 116-125.

GUÉDRON, S., L. HUGUET, D.A.L. VIGNATI, B. LIU, F. GIMBERT, B.J.D. FERRARI, R. ZONTA \& J. DOMINIK. 2012. Tidal cycling of mercury and methylmercury between sediments and water column in the Venice Lagoon (Italy). Mar. Chem., 130/131: 1-11.

GUERZONI, S., M. FRIGNANI, P. GIORDANI \& F. FRASCARI. 1984. Heavy metals in sediments from different environments of a northern Adriatic Sea area, Italy. Environ. Geol. Water Sci., 6: 111-119.

GUERZONI, S., M. RAVAIOLI, G. ROVATTI \& O.D. SUMAN. 1985. Comparison of ${ }^{210} \mathrm{~Pb}$, trace metals $(\mathrm{Hg}, \mathrm{Pb}, \mathrm{Cu}, \mathrm{Cr}$ ) profiles and river discharge in a core off the Po della Pila river mouth (Italy). In: Proceedings of the VII ${ }^{\text {th }}$ Workshop on Marine Pollution of the Mediterranean, Lucerne, Switzerland, 12-19 October. ICSEM, Lucerne, Switzerland, pp. 303-307.

HAMMERSCHMIDT, C. R. \& K. L. BOWMAN. 2012. Vertical methylmercury distribution in the subtropical North Pacific Ocean. Mar. Chem., 132-133: 77-82.

HEDGECOCK, I. M., N. PIRRONE, F. SPROVIERI \& E. PESENTI. 2003. Reactive gaseous mercury in the marine boundary layer: modelling and experimental evidence of its formation in the Mediterranean region. Atmos. Environ., 37(1): S41-S49.

HEIMBÜRGER, L.-E., D. COSSA, J.-C. MARTY, C. MIGON, B. AVERTY, A. DUFOUR \& J. RAS. 2010. Methyl mercury distributions in relation to the presence of nano- and picophytoplankton in an oceanic water column (Ligurian Sea, North-western Mediterranean). Geochim. Cosmochim. Ac., 74: 5549-5559.

HINES, M.E., M. HORVAT, J. FAGANELI, J.-C.J. BONZONGO, T. BARKAY, E.B. MAJOR, K.J. SCOTT, E.A. BAILEY, J.J. WARWICK \& W.B. LYONS. 2000. Mercury Biogeochemistry in the Idrija River, Slovenia, from above the Mine into the Gulf of Trieste. Environ. Res., 83(2): 129-139.

HINES, M.E., E.N. POITRAS, S. COVELLI, J. FAGANELI, A. EMILI, S. ŽIŽEK \& M. HORVAT. 2012. Mercury methylation and demethylation in Hg-contaminated lagoon sediments (Marano \& Grado Lagoons, Italy). Est. Coast. Shelf Sci., 113: 85-95.

HOLMES, C. D., D. J. JACOB, R. P. MASON \& D. A. JAFFE. 2009. Sources and deposition of reactive gaseous mercury in the marine atmosphere. Atmos. Environ., 43: 2278-2285.

HORVAT, M. 2005. Determination of mercury and its compounds in water, sediment, soil and biological samples. In: N. Pirrone \& K.R. Mahaffey (Editors). Dynamics of Mercury Pollution on Regional and Global Scales: Atmospheric Processes and Human Exposures around the World. Springer Science, New York, USA, pp. 153-190.

HORVAT, M., S. COVELLI, J. FAGANELI, M. LOGAR, V. MANDIĆ, R. RAJAR, A. ŠIRCA \& D. ŽAGAR. 1999. Mercury in contaminated coastal environments; a case study: the Gulf of Trieste. Sci. Total Environ., 237/238: 43-56.

HORVAT, M., J. KOTNIK, M. LOGAR, V. FAJON, T. ZVONARIĆ \& N. PIRRONE. 2003. Speciation of mercury in surface and deep-sea waters in the Mediterranean Sea. Atmos. Environ., 37(1): S93-S108.

HORVAT, M., N. DEGENEK, L. LIPEJ, J. SNOJ TRATNIK \& J. FAGANELI. 2014. Trophic transfer and accumulation of mercury in ray species in coastal waters affected by historic mercury mining (Gulf of Trieste, northern Adriatic Sea). Environ. Sci. Pollut. Res., 21: 41634176.

KIM, M., S. HAN, J. GIESKES \& D.D. DEHEYN. 2011. Importance of organic matter lability for monomethylmercury production in sulfaterich marine sediments. Sci. Total Environ., 409: 778-784.

KLJAKOVIĆ-GAŠPIĆ, Z., N. ODŽAK, I. UJEVIĆ, T. ZVONARIĆ, M. HORVAT \& A. BARIĆ. 2006. Biomonitoring of mercury in polluted coastal area using transplanted mussels. Sci. Total Environ., 368: 199-209.

KORON, N. \& J. FAGANELI. 2012. Benthic fluxes 
of mercury during redox changes in pristine coastal marine sediments from the Gulf of Trieste (northern Adriatic Sea). J. Soils Sediments, 12: 1604-1614.

KOSTA, L., V. RAVNIK, A.R. BYRNE, J. ŠTIRN, M. DERMELJ \& P. STEGNAR. 1978. Some trace elements in the waters, marine organisms and sediments of the Adriatic by neutron activation analysis. J. Radioanal. Chem., 44: 317-332.

KOTNIK, J., M. HORVAT, E. TESSIER, N. OGRINC, M. MONPERRUS, D. AMOUROUX, V. FAJON, D. GIBIČAR, S. ŽIŽEK, F. SPROVIERI \& N. PIRRONE. 2007. Mercury speciation in surface and deep waters of the Mediterranean Sea. Mar. Chem., 107(1): 13-30.

KOTNIK, J., F. SPROVIERI, N. OGRINC, M. HORVAT $\&$ N. PIRONNE. 2013. Mercury in the Mediterranean, part I: spatial and temporal trends. Environ. Sci. Pollut. Res., 21: 4063-4080.

KOTNIK, J., M. HORVAT, N. OGRINC, V. FAJON, D. ŽAGAR, D. COSSA, F. SPROVIERI \& N. PIRRONE. 2015. Mercury speciation in the Adriatic Sea. Mar. Pollut. Bull., 96: 136-148.

KWOKAL，Ž., S. FRANČIŠKOVIĆ-BILINSKI， H. BILINSKI \& M. BRANICA. 2002. A comparison of anthropogenic mercury pollution in Kaštela Bay (Croatia) with pristine estuaries in Öre (Sweden) and Krka (Croatia). Mar. Pollut. Bull., 44: 1152-1169.

KWOKAL, Ž. \& M. LOVRIĆ. 2006. Vertical distribution of mercury in the Krka river estuary. Intern. J. Environ. Anal. Chem., 86: $905-$ 914.

LANZILLOTTA, E., C. CECCARINI \& R. FERRARA 2002. Photo-induced formation of dissolved gaseous mercury in coastal and offshore seawater of the Mediterranean basin. Sci. Total Environ., 300: 179-187.

LAZO, P. \& A. CULLAY. 2002. Determination of different states of mercury in seawater near the Vlora and Durres Bays. Anal. Bioanal. Chem., 374: 1034-1038.

LEHNHERR, I., V.L. ST. LOUIS, H. HINTELMANN \& J.L. KIRK. 2011. Methylation of inorganic mercury in polar marine waters. Nat. Geosci., 4: 298-302.

MANTOVAN, P., L.M. VITTURI, B. PAVONI \& S. RAB-
ITTI. 1985. Sediments and pollution in the Northern Adriatic Sea: a statistical analysis. Cont. Shelf Res., 4: 321-340.

MASON, R.P., A.L. CHOI, W.F. FITZGERALD, C.R. HAMMERSCHMIDT, C.H. LAMBORG, A.L. SOERENSEN \& E.M. SUNDERLAND. 2012. Mercury biogeochemical cycling in the ocean and policy implications. Environ. Res., 119: 101-117.

MATTEUCCI, G., P. ROSSINI, S. GUERZONI, A. ARCANGELI, P. FONTI, L. LANGONE \& S. MISEROCCHI. 2005. Recent evolution of sedimentary heavy metals in a coastal lagoon contaminated by industrial wastewaters (Pialassa Baiona, Ravenna, Italy). Hydrobiologia, 550: 167-173.

MELAKU CANU, D., G. ROSATI, C. SOLIDORO, L.-E. HEIMBÜRGER \& A. ACQUAVITA. 2015. A comprehensive assessment of the mercury budget in the Marano-Grado Lagoon (Adriatic Sea) using a combined observational modelling approach. Mar. Chem., 177: 742-752.

MIKAC, N., Z. KWOKAL, K. MAY \& M. BRANICA. 1989. Mercury distribution in the Krka river Estuary (Eastern Adriatic Coast). Mar. Chem., 28: 109-126.

MIKAC, N., V. ROJE, N. CUKROV \& D. FOUCHER. 2006. Mercury in Aquatic sediments and Soils from Croatia. Arh. Hig. Rada Toksikol., 57: 325-332.

MILLOT, C. \& I. TAUPIER-LETAGE. 2005. Circulation in the Mediterranean Sea. In: A. Saliot (Editor). The Mediterranean Sea; The Handbook of Environmental Chemistry, 5K. SpringerVerlag, Berlin, Germany, pp. 29-66.

MONPERRUS, M., E. TESSIER, D. AMOUROUX, A. LEYNAERT, P. HUONNIC \& O.F.X. DONARD. 2007a. Mercury methylation, demethylation and reduction rates in coastal and marine surface waters of the Mediterranean Sea. Mar. Chem., 107: 49-63.

MONPERRUS, M., E. TESSIER, D. POINT, K. VIDIMOVA, D. AMOUROUX, R. GUYONEAUD, A. LEYNAERT, J. GRALL, L. CHAUVAUD, G. THOUZEAU \& O. F. X. DONARD. 2007b. The biogeochemistry of mercury at the sedimentwater interface in the Thau Lagoon. 2. Evaluation of mercury methylation potential in 
both surface sediment and the water column. Estuar. Coast. Shelf Sci., 72: 485-496.

NITTROUER, C., S. MISEROCCHI \& F. TRINCARDI. 2004. The PASTA Project: Investigation of Po and Apennine Sediment Transport and Accumulation. Oceanography, 17: 46-57.

O'DRISCOLL, N. J., A. RENCZ \& D. R. S. LEAN. 2005. The biogeochemistry and fate of mercury in the environment. In: A. Sigel, H. Sigel \& R. K. O. Sigel (Editors). Metal Ions in Biological Systems, Volume 43 - Biogeochemical Cycles of Elements. Taylor \& Francis, Boca Raton, USA, pp. 221-238.

OGRINC, N., M. MONPERRUS, J. KOTNIK, V. FAJON,

K. VIDIMOVA, D. AMOUROUX, D. KOCMAN, E. TESSIER, S. ŽIŽEK \& M. HORVAT. 2007. Distribution of mercury and methylmercury in deep-sea surficial sediments of the Mediterranean Sea. Mar. Chem., 107: 31-48.

PELLEGRINI, D., M. GIANI \& P. COPPOLELLI. 1992. Mercury and Chromium in organisms of the coastal marine area between Po Delta and Ravenna Harbour. Rapp. Comm. Int. Mer Medit., 33: 325.

PIRRONE, N., S. CINNIRELLA, X. FENG, R. B. FINKELMAN, H. R. FRIEDLI, J. LEANER, R. MASON, A. B. MUKHERJEE, G. B. STRACHER, D. G. STREETS \& K. TELMER. 2010. Global mercury emissions to the atmosphere from anthropogenic and natural sources. Atmos. Chem. Phys., 10: 2951-5964.

QARRI, F., S. KANE \& P. LAZO. 2014. Environmental assessment of dissolved heavy metals in Vlora Bay, Albania. Fresen. Environ. Bull., 23: 1539-1546.

QURESHI, A., N. J. O'DRISCOLL, M. MACLEOD, Y.-M. NEUHOLD \& K. HUNGERBÜHLER. 2010. Photoreactions of mercury in surface ocean water: Gross reaction kinetics and possible pathways. Environ. Sci. Technol., 44: 644649.

SELLI, R., M. FRIGNANI, C.M. ROSSI \& R. VIVIANI. 1973. The mercury content in the sediments of the Adriatic and the Tyrrhenian. Bull. Geol. Soc. Greece, 10: 177-179.

SOERENSEN, A. L., E. M. SUNDERLAND, C. D. HOLMES, D. J. JACOB, R. M. YANTOSCA, H. SKOV, J. H. CHRISTENSEN, S. A. STRODE \& R. P. MASON.
2010. An improved global model for air-sea exchange of mercury: high concentrations over the North Atlantic. Environ. Sci. Technol., 44: 8574-8580.

SPROVIERI, F., N. PIRRONE, K. GÅRDFELDT \& J. SOMMAR. 2003. Mercury speciation in the marine boundary layer along a $6000 \mathrm{~km}$ cruise path around the Mediterranean Sea. Atmos. Environ., 37: S63-S71.

SPROVIERI, F., I.M. HEDGECOCK \& N. PIRRONE. 2010. An investigation of the origins of reactive gaseous mercury in the Mediterranean marine boundary layer. Atmos. Chem. Phys., 10: 3985-3997.

STORELLI, M.M., R. GIACOMINELLI STUFFLER \& G.O. MARCOTRIGIANO. 1998. Total mercury in muscle of benthic and pelagic fish from the South Adriatic Sea (Italy). Food. Addit. Contam., 15(8):876-883.

ŠOliĆ, M., N. KRSTULOVIĆ, G. KUŠPILIĆ, Ž. NINČEVIĆ GLADAN, N. BOJANIĆ, S. ŠESTANOVIĆ, D. ŠANTIĆ \& M. ORDULJ. 2010. Changes in microbial food web structure in response to changed environmental trophic status: A case study of the Vranjic Basin (Adriatic Sea). Mar. Environ. Res., 70: 239249.

ŠOliĆ, M., N. KRSTUlOVIĆ, S. ŠESTANOVIĆ, D. ŠANTIĆ, N. BOJANIĆ, M. ORDULJ \& S. JOZIĆ. 2016. Microbial Community Ecology of the Adriatic Sea. Lambert Academic Publishing, Saarbrucken, Germany, 436 pp.

TROMBINI, C., D. FABBRI, M. LOMBARDO, I. VASSURA, E. ZAVOLI \& M. HORVAT. 2003. Mercury and methylmercury contamination in surficial sediments and clams of a coastal lagoon (Pialassa Baiona, Ravenna, Italy). Cont. Shelf Res., 23: 1821-1831.

UNEP. 2012. Initial integrated assessment of the Mediterranean Sea - fulfilling step 3 of the ecosystem approach process. UNEP/MAP, Athens, Greece, 246 pp.

UNEP. 2013. Global Mercury Assessment 2013: Sources, Emissions, Releases and Environmental Transport. UNEP Chemicals Branch, Geneva, Switzerland, 42 pp.

ZHANG, L., L. P. WRIGHT \& P. BLANCHARD. 2009. A review of current knowledge concerning dry 
deposition of atmospheric mercury. Atmos. Environ., 43: 5853-5864.

ZVONARIĆ, T. 1991. The cycling of Mercury through the marine environment of Kaštela Bay. In: UNEP/FAO/IAEA. Proceedings of the FAO/UNEP/IAEA Consultation Meeting on the Accumulation and Transformation of Chemical Contaminants by Biotic and Abi- otic Processes in the Marine Environment. UNEP, Athens, Greece, pp. 369-381.

ŽAGAR, D., N. SIRNIK, M. ČETINA, M. HORVAT, J. KOTNIK, N. OGRINC, I.M. HEDGECOCK, S. CINNIRELLA, F. DE SIMONE, C.N. GENCARELLI \& N. PIRRONE. 2013. Mercury in the Mediterranean. Part 2: processes and mass balance. Environ. Sci. Pollut. Res., 21: 4081-4094.

Received: 21 August 2016

Accepted: 2 November 2016

\title{
Zastupljenost, raspodjela i specijacija žive u vodama i sedimentima Jadranskog mora - pregled
}

\author{
Igor ŽIVKOVIĆ, Jože KOTNIK, Mladen ŠOLIĆ i Milena HORVAT* \\ *Kontakt adresa, e-pošta: milena.horvat@ijs.si
}

\begin{abstract}
SAŽETAK
Ovaj pregledni članak usredotočuje se na specijaciju žive u Jadranskom moru, rubnom moru Mediterana, koje predstavlja njegovu posebnu biogeokemijsku podjedinicu zbog antropoloških izvora žive. Trenutno znanje o kruženju žive u Jadranu je predstavljeno kroz pregled vrhunskih istraživanja na ovom području o vremenskim i prostornim raspodjelama i pojavnostima živinih specija u vodi i sedimentu te kemijskim transformacijama. Sumirani su rezultati istraživanja o specijaciji žive kako bi se opisala njena prisutnost i sudbina u Jadranskom moru. Jadransko more predstavlja neto izvor žive u Sredozemlju zbog najviših koncentracija ukupne žive uočenih u sjevernom Jadranu te najviših koncentracija metilžive u južnojadranskom ponoru. Međutim, biogeokemijski ciklus žive nije u potpunosti poznat te je ograničeno naše razumijevanje živinog transporta između odjeljaka i njenih (bio)transformacija. Buduće istraživanje se treba usredotočiti na mikrobne i kemijske procese živinih transformacija kako bi se bolje razumio utjecaj kontaminacije živom na okoliš i zdravlje ljudi u Jadranskom moru.
\end{abstract}

Ključne riječi: živa, kemijska specijacija, metilživa, Jadran, Sredozemlje 